\title{
Expression pattern of in vitro organogenesis-associated genes as transcriptional marker in Indian Sandalwood (Santalum album L.)
}

Gareema Pandey ${ }^{1 *}$, Arpan $\mathrm{Modi}^{2}, \mathrm{Shikha} \mathrm{Shah}^{2}$, Ghanshyam Patil ${ }^{2}$ and Subhash Narayanan ${ }^{2}$

${ }^{1}$ Western Sydney University, Richmond, New South Wales, Australia

2 Plant Tissue Culture Laboratory, Anand Agricultural University, Anand, Gujarat, India

Corresponding author:

Gareema Pandey

$\mathrm{PhD}$ candidate

Western Sydney University, Richmond campus

School of Sciences

New South Wales

Australia

Email address: 20618748@ student.westernsydney.edu.au 


\begin{abstract}
Indian sandalwood (Santalum album L.) is an expensive wood that requires reproducible method for mass propagation to ensure consistent production and sustainable use of sandalwood. For mass propagation of sandalwood, plant organogenesis requires different combinations of the tissue culture medium. The media is composed of exogenous phytohormones which decides the explant's morphological stages such as shooting or rooting induction. Early prediction of morphological stage from explant can potentially help in selecting the exogenous phytohormones combinations thereby saving time and resources for mass sandalwood propogation. An efficient protocol for the direct and indirect organogenesis (up to shooting development phase) of sandalwood were developed using Woody Plant Media (WPM). WPM supplemented with various concentrations of 6-Bezylaminopurine (BAP) and 1-Naphthaleneacetic acid (NAA) were tested for direct organogenesis, while different treatments consisting of various levels of 2,4dichlorophenoxyacetic acid (2,4-D), NAA, BAP, Adenine sulphate (ADS), glycine and potassium nitrate were tested for indirect organogenesis. Three stages of leaf development were selected viz., the leaf just after inoculation in WPM media, initial stage of callus formation from leaf and shoot formation for expression pattern analysis. The targeted genes were Alternative oxidase (ao), Late embryogenesis abundant (lea), Cytochrome P450 (cyt-p450), ABC transporter (abct), and Serine-threonine phosphatase (stp) which are associated with in vitro organogenesis. The expression patterns were evaluated to identify a transcription marker. During the initial stages of organogenesis, ao, cyt-p450 and abct showed no/little change in expression in the direct pathway but up-regulation of $a o$ and $a b c t$ and downregulation of $c y t-p 450$ were observed in the indirect pathway. Expression of lea was increased up to 70-fold during direct and dropped to half during indirect organogenesis.
\end{abstract}

Key words: Absolute quantification, Micropropagation, Organogenesis, qPCR, Sandalwood 


\section{Introduction}

Indian sandalwood (Santalum album L.) is one of the tree species popularly known as 'The Royal Tree' of the plant kingdom (Subasinghe 2013). Santalum album L., belongs to the family Santalaceae, is an approximately 12-15 meters tall, evergreen and hemi-root parasitic tree. In India, Indian sandalwood is more confined to the southern part, especially in Karnataka, Tamil Nadu, and Kerala (Kumar et al. 2012) and highly valued for its fragrant heartwood and medicinal purposes. Sandalwood has the capacity to grow under diverse conditions, viz. adaptability to low rainfall and wide variety of soil types and has innate survival capacity, short juvenile phase, and profuse coppicing ability (Singh et al. 2013). Though, the major constraints in growing sandalwood are long seed dormancy period (ranges from 2 months to 12 months and normally take 4-8 weeks for the germination) and flowering usually occurs after 3-4 years in only 60\% plants (Srimathi et al. 1995). Due to limited regeneration ability and high demand of sandalwood products consequently increased sandalwood tree depletion rate. The over exploitation of sandalwood tree require an efficient solution for its conservation. For sandalwood conservation, since the conventional breeding methods is one of the techniques for creating consistency in production. However it is an expensive and difficult process because sandalwood has long generation time and heterozygous in nature (Rugkhla and Jones 1998).

Alternatively, in vitro organogenesis through micropropogation is the potential approach for rapid sandalwood propagation that fulfills the scarcity of sandalwood in the market (Mujib 2005). In vitro organogenesis consist of phytohormone application which initiates cell division from any plant parts to form specific organ primordia and meristems. As the technique rely on the application of exogenous phytohormones, in particular gradients in the concentration of auxin and cytokinin and also on the ability of the tissue to respond to these phytohormones (Thorpe 1990). Therefore, different combinations and gradients of pytohormones has been used for direct and indirect organogenesis pathways as an approach for sandalwood tree regeneration.

Further, to develop a better understanding of the physiological and molecular basis of regeneration potential in sandalwood, the gene expression analysis by reverse transcription (RT) followed by quantitative polymerase chain reaction (qPCR) was performed. At molecular level, switching to direct or indirect organogenesis at any developmental stage involves differential gene expression (Jain and Minocha 2013). It has been postulated that the different hormonal treatments induce different response in genes, and it is reflective in transcript number. RT- qPCR technique represents a powerful tool for the detection and quantification of mRNA. Since qPCR is the most sensitive method for the detection and quantification of gene expression levels in particular for low transcripts in tissues (Freeman et al. 1999; Steuerwald et al. 1999; Mackay et al. 2002). Therefore, with the consideration of the importance of organogenesis in sandalwood tissue culture and the genetic expression of genes involved in direct and indirect organogenesis, 
the present investigation for standardization of tissue culture protocol and genetic expression was carried out.

\section{Materials and Methods}

\section{Experimental material}

Tender nodes were collected from approximately 20 years old sandalwood tree cultivated at Anand Agricultural University Campus, Anand, Gujarat, India. The 2-3 cm long stems containing nodes were selected as explants and surface sterilized using $1 \mathrm{mlL}^{-1}$ Tween-20 (5 minutes), $1000 \mathrm{mgL}^{-1}$ Carbendazim-50\% (7 minutes), $200 \mathrm{mgL}^{-1}$ Cefotaxime (5 minutes), 200 $\mathrm{mgL}^{-1}$ Kanamycin (5 minutes) and $1000 \mathrm{mgL}^{-1}$ mercuric chloride (3 minutes). Surface sterilized explants were then inoculated on MS medium for the shoot induction response. Leaves emerged from the nodes were used as the experimental material in the present investigation.

\section{Direct and Indirect Organogenesis}

For both the organogenesis pathways, direct and indirect, in vitro leaves were placed on the shoot induction media. The shoot induction media for direct organogenesis was comprised of Woody Plant Medium (WPM) (Lloyd and McCown 1981) supplemented with various combinations of 6-Benzylaminopurine (BAP) and 1-Naphthaleneacetic acid (NAA) and 3\% w/v sucrose (Table 1) while the shoot induction media for indirect organogenesis was comprised of WPM supplemented with various combinations of Glycine, Adenine Sulphate (ADS), Potassium nitrate $\mathrm{KNO}_{3}$ ), NAA, BAP, 2,4-Dichlorophenoxyacetic acid (2,4-D) and 3\% w/v sucrose (Table 2). The $\mathrm{KH}_{2} \mathrm{PO}_{4}$ concentrations for direct and indirect pathways were $170 \mathrm{mgL}^{-1}$ and $85 \mathrm{mgL}^{-1}$, respectively while the $\mathrm{K}_{2} \mathrm{SO}_{4}$ concentrations for direct and indirect pathways were $990 \mathrm{mgL}^{-1}$ and $495 \mathrm{mgL}^{-1}$, respectively. The media was jellified using 0.9\% Agar and the $\mathrm{pH}$ of the medium was adjusted to $5.7 \pm 0.01$. All the cultures were incubated in a growth room maintained at $25 \pm 1^{\circ} \mathrm{C}$, 40-60\% relative humidity and 16/8-hour light/dark regime was provided by a cool-white, fluorescent lights having $36 \mu \mathrm{molm}^{-2} \mathrm{~s}^{-1}$ intensity. Observation on bud frequency $\%$, area covered by bud sprouting $(\%)$, number of shoots, length of shoots $(\mathrm{cm})$, days to callus induction, callus induction $(\%)$, callus frequency $(\%)$, callus type, callus color and health range were recorded at the end of 40, 80 and 120 days. 
Table 1. Treatments for direct organogenesis

\begin{tabular}{|c|c|c|c|}
\hline Media code & Basal & BAP( $\left.\mathbf{m g l}^{-\mathbf{1}}\right)$ & $\mathbf{N A A}\left(\mathbf{m g l}^{-\mathbf{1}}\right)$ \\
\hline $\mathrm{SD}_{1}$ & WPM & 0 & 0 \\
\hline $\mathrm{SD}_{2}$ & WPM & 1 & 0 \\
\hline $\mathrm{SD}_{3}$ & WPM & 1.5 & 0 \\
\hline $\mathrm{SD}_{4}$ & WPM & 2 & 0 \\
\hline $\mathrm{SD}_{5}$ & WPM & 2.5 & 0 \\
\hline $\mathrm{SD}_{6}$ & WPM & 0 & 0.2 \\
\hline $\mathrm{SD}_{7}$ & WPM & 1 & 0.2 \\
\hline $\mathrm{SD}_{8}$ & WPM & 1.5 & 0.2 \\
\hline $\mathrm{SD}_{9}$ & WPM & 2 & 0.2 \\
\hline $\mathrm{SD}_{10}$ & WPM & 2.5 & 0.2 \\
\hline $\mathrm{SD}_{11}$ & WPM & 0 & 0.4 \\
\hline $\mathrm{SD}_{12}$ & WPM & 1 & 0.4 \\
\hline $\mathrm{SD}_{13}$ & WPM & 1.5 & 0.4 \\
\hline $\mathrm{SD}_{14}$ & WPM & 2 & 0.4 \\
\hline $\mathrm{SD}_{15}$ & WPM & 2.5 & 0.4 \\
\hline
\end{tabular}

All treatments have been provided $3 \%$ sucrose with $0.9 \%$ agar

BAP $=6$-Benzylaminopurine

NAA $=1-$ Naphthaleneacetic acid $\mathrm{WPM}=$ Woody plant media 
Table 2. Treatments for indirect organogenesis

\begin{tabular}{|c|c|c|c|c|c|c|c|}
\hline $\begin{array}{l}\text { Media } \\
\text { code }\end{array}$ & $\begin{array}{c}\text { Media } \\
\text { composition }\end{array}$ & $\begin{array}{c}\text { BAP } \\
\left(\mathrm{mgL}^{-1}\right)\end{array}$ & $\begin{array}{c}2,4- \\
D\left(\mathrm{mgL}^{-1}\right)\end{array}$ & $\begin{array}{l}\text { Glycin } \\
\left(\mathrm{mgL}^{-1}\right)\end{array}$ & $\begin{array}{c}\text { ADS } \\
\left(\mathrm{mgL}^{-1}\right)\end{array}$ & $\begin{array}{c}\mathrm{KNO3} \\
\left(\mathrm{mgL}^{-1}\right)\end{array}$ & $\begin{array}{c}\text { NAA } \\
\left(\mathrm{mgL}^{-1}\right)\end{array}$ \\
\hline $\mathrm{SI}_{1}$ & WPM & - & - & - & - & - & - \\
\hline $\mathrm{SI}_{2}$ & Modified WPM & 0 & 1 & - & - & - & - \\
\hline $\mathrm{SI}_{3}$ & Modified WPM & 0.5 & 1 & - & - & - & - \\
\hline $\mathrm{SI}_{4}$ & Modified WPM & 1 & 1 & - & - & - & - \\
\hline $\mathrm{SI}_{5}$ & Modified WPM & 0 & 2 & - & - & - & - \\
\hline $\mathrm{SI}_{6}$ & Modified WPM & 0.5 & 2 & - & - & - & - \\
\hline $\mathrm{SI}_{7}$ & Modified WPM & 1 & 2 & - & - & - & - \\
\hline $\mathrm{SI}_{8}$ & Modified WPM & 0.5 & 2.5 & - & - & - & - \\
\hline $\mathrm{SI}_{9}$ & Modified WPM & 0 & 2.5 & - & - & - & - \\
\hline $\mathrm{SI}_{10}$ & Modified WPM & 1 & 2.5 & - & - & - & - \\
\hline $\mathrm{SI}_{11}$ & Modified WPM & 0 & 5 & - & - & - & - \\
\hline $\mathrm{SI}_{12}$ & Modified WPM & 0.5 & 5 & - & - & - & - \\
\hline $\mathrm{SI}_{13}$ & Modified WPM & 1 & 5 & - & - & - & - \\
\hline $\mathrm{SI}_{14}$ & WPM & - & - & 1 & - & - & - \\
\hline $\mathrm{SI}_{15}$ & WPM & - & - & 1 & 25 & - & - \\
\hline $\mathrm{SI}_{16}$ & WPM & - & - & 1 & 25 & - & - \\
\hline $\mathrm{SI}_{17}$ & WPM & - & 2 & 1 & - & - & - \\
\hline $\mathrm{SI}_{18}$ & WPM & - & 3 & 1 & 25 & - & - \\
\hline $\mathrm{SI}_{19}$ & WPM & - & 2 & - & - & 630 & - \\
\hline $\mathrm{SI}_{20}$ & WPM & - & 3 & - & - & - & - \\
\hline $\mathrm{SI}_{21}$ & WPM & - & 0.5 & - & - & - & - \\
\hline $\mathrm{SI}_{22}$ & WPM & - & 1 & - & - & - & - \\
\hline $\mathrm{SI}_{23}$ & WPM & - & 1.5 & - & - & - & - \\
\hline $\mathrm{SI}_{24}$ & WPM & - & 2.5 & - & - & - & - \\
\hline $\mathrm{SI}_{25}$ & WPM & - & 2 & - & - & - & - \\
\hline $\mathrm{SI}_{26}$ & WPM & - & 3.5 & - & - & - & - \\
\hline $\mathrm{SI}_{27}$ & WPM & - & 4 & - & - & - & - \\
\hline $\mathrm{SI}_{28}$ & WPM & - & 4.5 & - & - & - & - \\
\hline $\mathrm{SI}_{29}$ & WPM & - & 5.0 & - & - & - & - \\
\hline $\mathrm{SI}_{30}$ & WPM & - & 3 & - & - & - & - \\
\hline $\mathrm{SI}_{31}$ & WPM & 0 & 0.5 & - & - & - & - \\
\hline $\mathrm{SI}_{32}$ & WPM & 1 & 0 & - & - & - & - \\
\hline $\mathrm{SI}_{33}$ & WPM & 1 & 0.5 & - & - & - & - \\
\hline $\mathrm{SI}_{34}$ & WPM & 2 & 0 & - & - & - & - \\
\hline $\mathrm{SI}_{35}$ & WPM & 2 & 0.5 & - & - & - & - \\
\hline $\mathrm{SI}_{36}$ & WPM & 4 & 0 & - & - & - & 0.4 \\
\hline
\end{tabular}

All treatments have been provided $3 \%$ sucrose with $0.9 \%$ agar 
Modified WPM $=$ Half of macronutrients $\mathrm{ADS}=$ Adenine sulphate

$\mathrm{BAP}=6$-Benzylaminopurine

WPM $=$ Woody plant media
2, 4-D = 2, 4-Dichlorophenoxyacetic acid NAA $=1-$ Naphthaleneacetic acid $\mathrm{KNO}_{3}=$ Potassium nitrate

\section{Composition of WPM (Woody Plant Media)}

\begin{tabular}{|c|c|c|c|c|c|}
\hline \multirow{2}{*}{ Stock } & \multirow{2}{*}{ Chemical } & \multirow{2}{*}{$\mathrm{Mgl}^{-1}$} & \multicolumn{3}{|c|}{ Stock } \\
\hline & & & $200 \mathrm{ml}$ & $500 \mathrm{ml}$ & $1000 \mathrm{ml}$ \\
\hline$L \& M-18$ & $\mathrm{Ca}\left(\mathrm{NO}_{3}\right)_{2} \mathrm{H}_{2} \mathrm{O}$ & 556 & $2224 \mathrm{mgs}$ & $5560 \mathrm{mgs}$ & $11120 \mathrm{mgs}$ \\
\hline $\mathbf{A}$ & $\mathrm{NH}_{4} \mathrm{NO}_{3}$ & 400 & $1600 \mathrm{mgs}$ & $4000 \mathrm{mgs}$ & $8000 \mathrm{mgs}$ \\
\hline $20 X$ & $\mathrm{CaCl}_{2} \cdot 2 \mathrm{H}_{2} \mathrm{O}$ & 96 & $384 \mathrm{mgs}$ & $960 \mathrm{mgs}$ & $1920 \mathrm{mgs}$ \\
\hline $50 \mathrm{mlL}^{-1}$ & $\mathrm{MgSO}_{4} .7 \mathrm{H}_{2} \mathrm{O}$ & 370 & $1480 \mathrm{mgs}$ & $3700 \mathrm{mgs}$ & $7400 \mathrm{mgs}$ \\
\hline \multirow{2}{*}{ Fresh } & $\mathrm{KH}_{2} \mathrm{PO}_{4}$ & 170 & & & \\
\hline & $\mathrm{K}_{2} \mathrm{SO}_{4}$ & 990 & & & \\
\hline \multirow[b]{2}{*}{$L \& M-18$} & & & $200 \mathrm{ml}$ & $500 \mathrm{ml}$ & $1000 \mathrm{ml}$ \\
\hline & $\mathrm{H}_{3} \mathrm{BO}_{3}$ & 6.2 & $124 \mathrm{mgs}$ & $310 \mathrm{mgs}$ & $620 \mathrm{mgs}$ \\
\hline B & $\mathrm{MnSO}_{4} \cdot 4 \mathrm{H}_{2} \mathrm{O}$ & 22.3 & $446 \mathrm{mgs}$ & $1115 \mathrm{mgs}$ & $2230 \mathrm{mgs}$ \\
\hline $100 X$ & $\mathrm{ZnSO}_{4} .7 \mathrm{H}_{2} \mathrm{O}$ & 8.6 & $172 \mathrm{mgs}$ & $430 \mathrm{mgs}$ & $860 \mathrm{mgs}$ \\
\hline \multirow[t]{2}{*}{$10 \mathrm{mlL}^{-1}$} & $\mathrm{Na}_{2} \mathrm{MoO}_{4} \cdot 2 \mathrm{H}_{2} \mathrm{O}$ & 0.25 & $5 \mathrm{mgs}$ & $12.5 \mathrm{mgs}$ & $25 \mathrm{mgs}$ \\
\hline & $\mathrm{CuSO}_{4} .5 \mathrm{H}_{2} \mathrm{O}$ & 0.25 & $5 \mathrm{mgs}$ & $12.5 \mathrm{mgs}$ & $25 \mathrm{mgs}$ \\
\hline$L \& M-18$ & & & $200 \mathrm{ml}$ & $500 \mathrm{ml}$ & $1000 \mathrm{ml}$ \\
\hline $\mathbf{F}$ & $\mathrm{Na}_{2}$ EDTA & 37.3 & 746 mgs & $1865 \mathrm{mgs}$ & $3730 \mathrm{mgs}$ \\
\hline
\end{tabular}




\begin{tabular}{|c|c|c|c|c|c|}
\hline $\begin{array}{c}100 \mathrm{X} \\
10 \mathrm{mlL}^{-1}\end{array}$ & $\mathrm{FeSO}_{4} .7 \mathrm{H}_{2} \mathrm{O}$ & 27.8 & $556 \mathrm{mgs}$ & $1390 \mathrm{mgs}$ & $2780 \mathrm{mgs}$ \\
\hline \multirow{3}{*}{$\begin{array}{l}\text { Mullin et al., (1974) } \\
\text { B } \quad \text { G }\end{array}$} & & & $200 \mathrm{ml}$ & $500 \mathrm{ml}$ & $1000 \mathrm{ml}$ \\
\hline & Nicotinic Acid & 0.5 & $10 \mathrm{mgs}$ & $25 \mathrm{mgs}$ & $50 \mathrm{mgs}$ \\
\hline & Pyridoxin HCL & 0.5 & $10 \mathrm{mgs}$ & $25 \mathrm{mgs}$ & $50 \mathrm{mgs}$ \\
\hline $100 X$ & Thiamin HCL & 1.0 & $20 \mathrm{mgs}$ & $50 \mathrm{mgs}$ & $50 \mathrm{mgs}$ \\
\hline \multirow[t]{2}{*}{$10 \mathrm{mlL}^{-1}$} & Glycin & 2.0 & $40 \mathrm{mgs}$ & $100 \mathrm{mgs}$ & $100 \mathrm{mgs}$ \\
\hline & Inositol & 100.0 & & & \\
\hline
\end{tabular}

Lloyd and McCown (1981)

\section{L \& M-81 Macro + L \& M-81 Micro + Mullin et al (1974) B (Vitamin) + Skoog (1944) A.A}

Gene expression profiling

In silico selection of genes and primer designing

A total of thirty-one various gene sequences for callus and shoot development stage were selected from the findings of Che et al. (2006) on Arabidopsis and subjected to BLAST analysis. Sequences for the primer design were selected from the conserved region of selected genes using primer BLAST tool available at NCBI web site. Two pairs of primers were selected for each of the in silico identified genes. The primers were checked for dimer or hairpin formation using Oligo IDT analyzer tool. Along with the gene specific primers, a DNA specific primer has also been designed from the intron region of gene to check the cDNA sample for DNA contamination. Five set of primers, representing five different genes viz. Alternative oxidase (ao), Late embryogenesis abundant proteins (lea), Cytochrome P-450 (cytp450), ATP binding cassette transporter proteins (abct), and Serine threonine phosphatase (stp) were designed using primer BLAST tool available at NCBI website (Table 3). 
Table 3. List of genes in callus development and shoot development in Arabidopsis

\begin{tabular}{|c|c|c|c|c|}
\hline $\begin{array}{l}\text { Sr. } \\
\text { No. }\end{array}$ & Gene & $\begin{array}{l}\text { Primer } \\
\text { Name }\end{array}$ & Sequence & $\begin{array}{c}\text { In silico } \\
\text { product } \\
\text { length } \\
\text { (bp) }\end{array}$ \\
\hline \multirow{2}{*}{1} & \multirow{2}{*}{ Alternative oxidase (AO) } & SW1 F & TGCCTGCACCGGCTATTG & \multirow{2}{*}{90} \\
\hline & & SW1 R & CTTCATCAGCACGGACCACC & \\
\hline \multirow{2}{*}{2} & \multirow{2}{*}{ LEA family protein (LEA) } & SW2 F & GAGAAGGGAAGCGAAGTGGG & \multirow{2}{*}{145} \\
\hline & & SW2 R & ACTCCGAAGCAAACTGAGCA & \\
\hline \multirow{2}{*}{3} & \multirow{2}{*}{ Cytochrome P-450 (CYTP450) } & SW3 F & AAGAGTCGGCTTACGAGCTG & \multirow{2}{*}{110} \\
\hline & & SW3 R & CTTGGGGCTGAAGAGATGGG & \\
\hline \multirow{2}{*}{4} & \multirow{2}{*}{$\begin{array}{l}\text { ATP Binding Cassette Transporter } \\
\text { proteins (ABCT) }\end{array}$} & SW4 F & GGATGAGCCAACTTCAGGCT & \multirow{2}{*}{82} \\
\hline & & SW4 R & TGCTAGGCTGGTGTATGGTG & \\
\hline \multirow{2}{*}{7} & \multirow{2}{*}{$\begin{array}{l}\text { Glyceraldehyde-3-phosphate } \\
\text { dehydrogenase (GAPDH) }\end{array}$} & SW5 F & ATGCGGACATTAAGGCTGCT & \multirow{2}{*}{113} \\
\hline & & SW5 R & TGACCTGTTGTCGCCAATGA & \\
\hline \multirow{2}{*}{6} & \multirow{2}{*}{$\begin{array}{l}\text { Serine Threonine Phosphatase } \\
\text { (STP) }\end{array}$} & SW6 F & CACACCGTGGTTGATGGCT & \multirow{2}{*}{150} \\
\hline & & SW6 R & TGAACGTGACCGGCAAAAAC & \\
\hline
\end{tabular}

DNA/RNA extraction, cDNA synthesis

Total DNA was extracted from the sandalwood leaf tissue using the method described by Doyle and Doyle (1990). The quantity and purity (A260/A280 ratio) of DNA was measured in Nanodrop N.D.1000 (Thermo Scientific, U.S.A.). The DNA samples were diluted to $20 \mathrm{ng} / \mu \mathrm{l}$ with TE buffer and stored at $4{ }^{\circ} \mathrm{C}$. Three developmental stages of sandalwood were selected for direct organogenesis, namely, inoculated leaf (D1), proliferated leaf (D2) and shoot formation stage (D3). Similarly for indirect organogenesis, the samples were collected from inoculated leaf (ID1), proliferated leaf (ID2) and callus formation stage (ID3). The various direct and indirect stages are shown in figure 1. RNA extraction was carried out from the samples collected from the different stages of organogenesis using the method described by Ghavana et al. (2011) with minor modification. The quantity and quality (A260/A280 ratio) of RNA was determined in 
Nanodrop N.D.1000 (Thermo Scientific, U.S.A.). DNase treatment was given to all the samples using DNase I (Thermo Scientific) to avoid any DNA contamination. Preparation of cDNA from total RNA was carried out using first strand cDNA synthesis kit (Takara, Japan) as per the manufacturer's instructions.

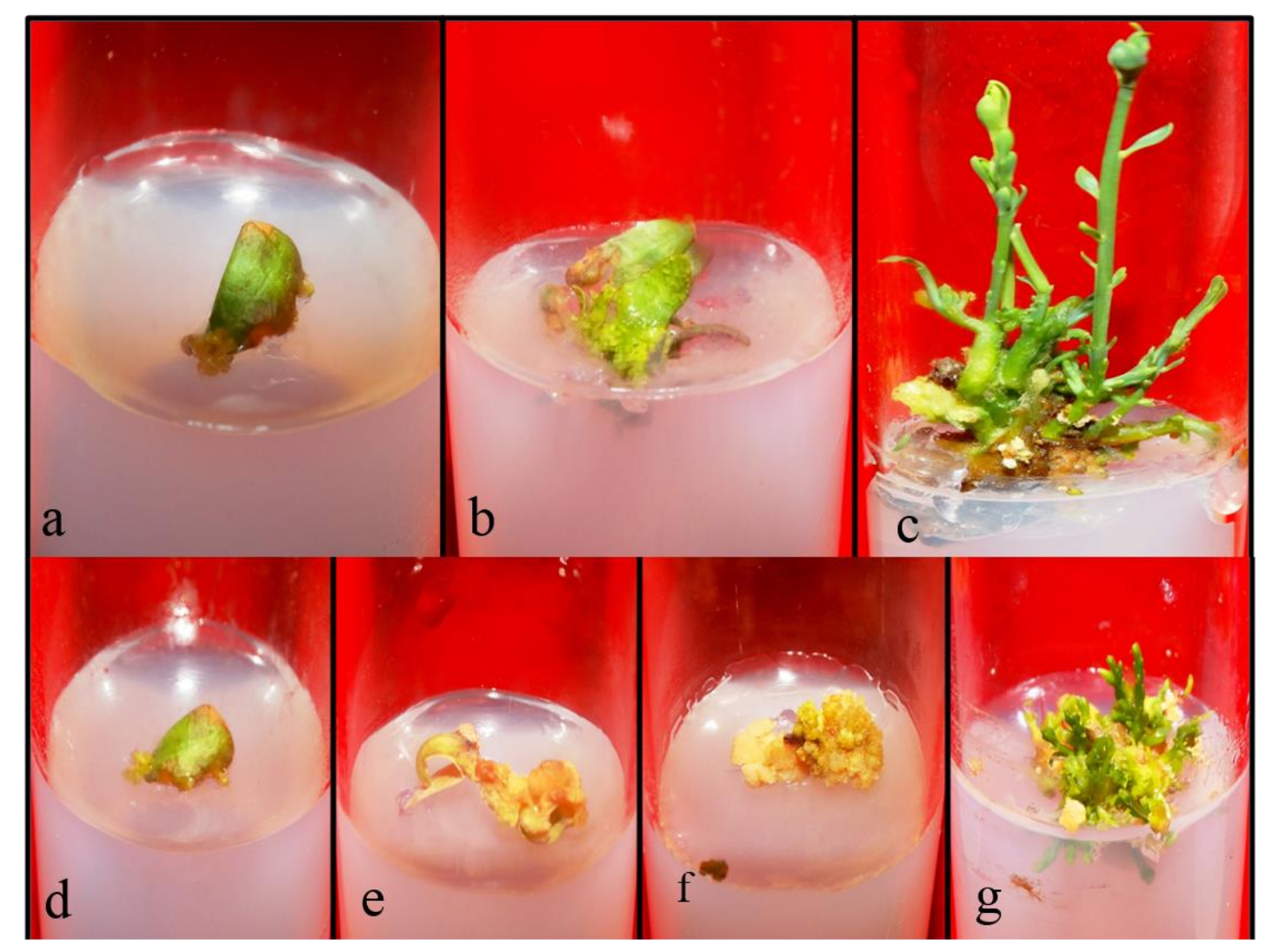

Fig. 1: Various developmental stages of direct $(a, b, c)$ and indirect (d, e, f, g) organogenesis in sandalwood; a \& d - Inoculated leaf; b \& e - Proliferated leaf; c \& g - Shoot formation; and f - Callus formation.

\section{Primer screening through end-point PCR and validation}

Primer screening was carried out with the DNA extracted from sandalwood tissues of different stages. RAPD amplification was performed in a $25 \mu 1$ reaction system containing 100 ng DNA, 1x DreamTaq Green PCR buffer with $2 \mathrm{mM} \mathrm{MgCl}_{2}$ (Thermo Fisher Scientific, U.S.A.), $0.2 \mathrm{mM}$ each of dNTPs (Thermo Fisher Scientific, U.S.A.), 0.5 U Taq DNA polymerase (Kapa Biosystems, U.S.A.), 4 pmol of forward and reverse primers (SW1, SW2, SW3, SW4, SW5 and 
SW6) and sterile distilled water. Amplification was automated using a PCR machine (Applied Biosystems, USA). The PCR cycles involved an initial denaturation step at $94{ }^{\circ} \mathrm{C}$ for 5 minutes followed by 35 cycles of denaturation at $94{ }^{\circ} \mathrm{C}$ for 1 minute, annealing at $60{ }^{\circ} \mathrm{C}$ for 30 seconds, extension at $72{ }^{\circ} \mathrm{C}$ for 1 minute and final extension at $72{ }^{\circ} \mathrm{C}$ for 5 minute. Agarose gel $(1.5 \%)$ was prepared in 1x TBE buffer to separate the amplified products. Gel documentation system (Alpha Innotech, USA) was used for visualization of amplified DNA fragments. Genes that did not amplify were eliminated and not considered for further downstream application. The screened primers were then validated with the cDNA of all samples to determine the genes expressed during organogenesis qualitatively. Each primer pair was amplified with all the samples along with an NTC (No template Control) to decipher the intensity of primer dimmers or DNA contamination. The primer pairs were selected on the basis of presence of specific and expected sized band in gel analysis. These primers were used for absolute quantification in Real Time PCR.

\section{Absolute quantification}

The preparation of standard curve of each gene was carried out by purifying and quantitating the PCR product for each gene. Standards for all the genes were ranged from $10^{9}$ to $10^{1}$ copies per $\mu \mathrm{l}$ with each step differing by 10 -fold. Using these standards and cDNA samples, absolute quantification was done in 7500 Fast Real Time PCR (Applied Biosystems, USA). SYBR Green chemistry was used for real time PCR reaction. Cycling conditions involved an initial denaturation at $94^{\circ} \mathrm{C}$ for 5 minutes and 40 cycles of amplification at $94^{\circ} \mathrm{C}$ for 10 seconds followed by $60^{\circ} \mathrm{C}$ for 30 seconds. Standard curve was prepared for each gene using Cq values and initial copy number of the transcript. Concentrations of unknown samples were determined using the data generated from the plot. Sample transcript copy number was calculated using the equation obtained from the graph. Moreover, considering the inoculated stage leaf (both D1 and ID1) as control, their transcript copy numbers were designated as 1.0 and corresponding relative numbers were given to other treatments.

\section{Results and discussion}

The present study used in vitro leaf tissue for direct as well as indirect organogenesis. The detailed consequences of the direct and indirect organogenesis and in vitro expression profiling of the various genes have been described here and elucidated through tables and figures. 


\section{In vitro organogenesis}

In attempts towards direct organogenesis, the relationship between gradient levels of BAP and NAA and the morphogenic potential of plantlets were found out which could give best establishment and multiplication rates. The percentage establishment and growth of cultures was highest in the establishment phase. After 40 days of incubation, treatment $\mathrm{SD}_{14}\left(2 \mathrm{mgL}^{-1} \mathrm{BAP}\right.$ and $0.4 \mathrm{mgL}^{-1} \mathrm{NAA}$ ) generated a sprouting frequency of $40 \%$. Treatment, $\mathrm{SD}_{14}$ and $\mathrm{SD}_{15}$ indicated as the best health representative among all treatments with score $(++++)$. Following $\mathrm{SD}_{14}, \mathrm{SD}_{15}$ showed second highest sprouting frequency (30\%). Remaining treatments demonstrated poor health with little necrotizing growth. In the proliferating phase, after 80 days, $\mathrm{SD}_{14}\left(2.0 \mathrm{mgL}^{-1} \mathrm{BAP}\right.$ and $\left.0.4 \mathrm{mgL}^{-1} \mathrm{NAA}\right)$ recurred as the best media in terms of the various observations recorded e.g. bud sprouting frequency, number of shoots and length of shoots were $60 \%, 3$ and $2 \mathrm{~cm}$, respectively, highest among the other treatments. Subsequently, $\mathrm{SD}_{7}$ was listed as the subsequent efficient media with $52.50 \%$ bud sprouting frequency and had an excellent shoot health $(++++)$. Even after 120 days, $\mathrm{SD}_{14}$ continued to give highest proliferation. The sprouting frequency has increased to $70 \%$ which was $40 \%$ earlier and number of shoots have increased to five. Treatments $\mathrm{SD}_{14}$ and $\mathrm{SD}_{7}$ came up with potential numbers of shoots formation per explant (five) after 120 days but considering the overall efficient health $\mathrm{SD}_{14}$ dominated over $\mathrm{SD}_{7}$. These observational analyses were in correlation with the report by Singh et al. (2013) where they used WPM supplemented with $2.5 \mathrm{mgL}^{-1}$ BAP and $0.2 \mathrm{mgL}^{-1} \mathrm{NAA}$ and obtained a bud frequency of $79.16 \%$, whereas incongruent with results of Mujib (2005) who reported the BAP concentration as low as $0.5 \mathrm{mgL}^{-1}$ without incorporating NAA. Greenish shoot bud formation in all the treatments in the present study might have been observed due to low auxin:cytokinin ratio as explained by the work of Behbahani et al. (2011) and Singh et al. (2013). The detailed results are presented in Supplementary Tables. Among all treatments tested, SI 24 (2.5 mgL $\mathrm{mg}^{-1}$ 2,4-D) followed by the treatment $\mathrm{SI}_{18}\left(3 \mathrm{mgL}^{-1} 2,4-\mathrm{D}\right.$ and $1 \mathrm{mgL}^{-1}$ glycine and 25 $\left.\mathrm{mgL}^{-1} \mathrm{ADS}\right)$ and $\mathrm{SI}_{33}\left(1 \mathrm{mgL}^{-1} \mathrm{BAP}\right.$ and $\left.0.5 \mathrm{mgL}^{-1} 2,4-\mathrm{D}\right)$ reflected as the best treatments for achieving early callus induction response after 40 days. This finding is in accordance with the results of Adesoye and Orkpeh (2009) and Behbahani et al. (2011) who also supported WPM over MS. Rashmi and Trivedi (2014) postulated that 2,4-D may have encouraged the synthesis of endogenous purines and cytokinins ultimately resulting in higher rates of cell division. The days to callus induction ranged from 35 to 37 days while the callus induction $\%$ ranged from $10 \%$ to $50 \%$. After 80 days, the callusing reached maximum in treatment, $\mathrm{SI}_{24}\left(2.5 \mathrm{mgL}^{-1} 2,4-\mathrm{D}\right)$ which generated callus induction and frequency percent of $70 \%$ and $50 \%$, respectively. The callus looked very healthy with green in colour and friable in nature. Tissue morphologies ranged from white, translucent and watery in appearance to green, opaque and compact. A few emerging propagules were observed as indicative of shoot regeneration in treatment $\mathrm{SI}_{33}\left(1 \mathrm{mgL}^{-1} \mathrm{BAP}\right.$ and $\left.0.5 \mathrm{mgL}^{-1} 2,4-\mathrm{D}\right)$ after 120 days. It generated callus induction percent of $87.50 \%$ and callus regeneration frequency percent of $75 \%$. Any change in the concentrations of growth regulators resulted in change in morphology and growth of the callus developmental pattern. Apart from control, treatments $\mathrm{SI}_{2}, \mathrm{SI}_{3}, \mathrm{SI}_{4}, \mathrm{SI}_{23}, \mathrm{SI}_{26}, \mathrm{SI}_{27}, \mathrm{SI}_{28}, \mathrm{SI}_{29}, \mathrm{SI}_{30}, \mathrm{SI}_{31}, \mathrm{SI}_{32}, \mathrm{SI}_{34}$ and $\mathrm{SI}_{36}$ were 
incompetent for leaf proliferation and shoot initiation even after 120 days. The detailed results are presented in Supplementary Table 1-6.

\section{Gene expression studies}

The screening of gene specific primers with various stages of sandalwood organogenesis cDNA samples was performed. The primers of genes which amplified the cDNA samples were Alternative oxidases, Cytochrome P-450, Late Embryogenesis Abundant, ABC transporter, and serine-threonine phosphatase and their product lengths recorded were $90 \mathrm{bp}, 82 \mathrm{bp}, 149 \mathrm{bp}, 150$ $\mathrm{bp}$, and $113 \mathrm{bp}$, respectively. The absolute quantification was performed for all mentioned primers in the real time PCR. Absolute quantification of each gene was carried out using standard curve as prepared from the graph of $\mathrm{C}_{\mathrm{q}}$ values versus copy number through which absolute copy number was calculated and converted into relative quantity value taking leaf inoculated sample (for both direct and indirect organogenesis) as control (Table 4, Figure 2, 3).
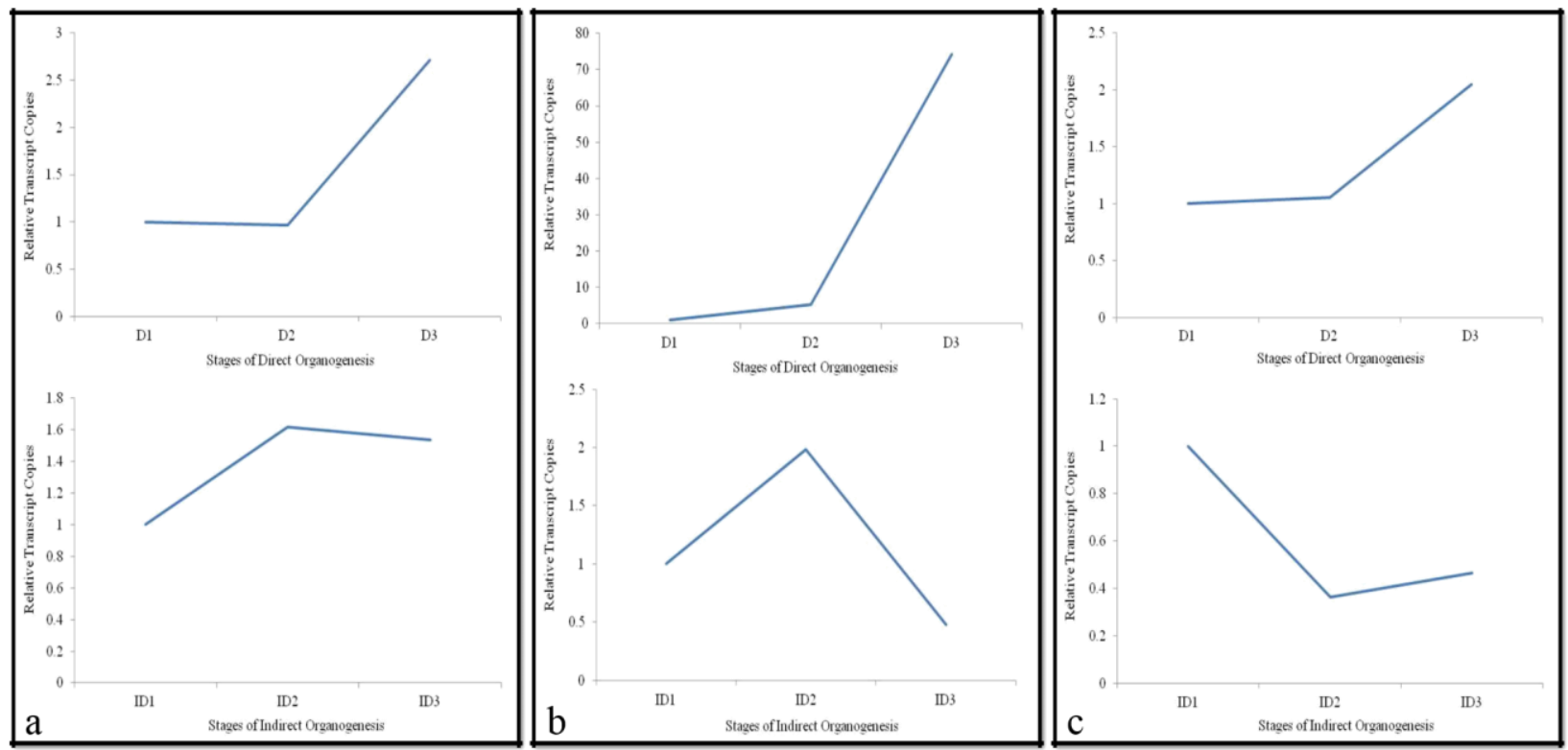

Fig. 2: Relative gene expression pattern of ao (a); lea (b); and cyt-P450 (c) within three stages of direct and indirect organogenesis. D1 - inoculated leaf, D2 - proliferated leaf and D3 shoot formation stage, ID1 - inoculated leaf, ID2 - proliferated leaf and ID3 - callus formation. 
Table 4. List of genes in callus development and shoot development (from Arabidopsis database) used for the gene expression profiling in micropropagation of S. album.

\begin{tabular}{|c|c|c|c|c|c|c|c|}
\hline $\begin{array}{l}\text { Sr. } \\
\text { No }\end{array}$ & Gene & $\begin{array}{c}\text { Prime } \\
\mathbf{r} \\
\text { name }\end{array}$ & $\begin{array}{c}\text { Sequence } \\
\left(5^{\prime}-3^{\prime}\right)\end{array}$ & $\begin{array}{c}\text { In } \\
\text { silico } \\
\text { produc } \\
\text { t length } \\
\text { (bp) }\end{array}$ & $\begin{array}{c}\text { Stag } \\
\mathbf{e}\end{array}$ & 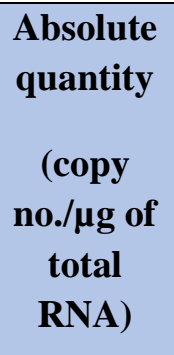 & $\begin{array}{c}\text { Relativ } \\
\text { e } \\
\text { quantit } \\
y\end{array}$ \\
\hline \multirow{6}{*}{1} & \multirow{6}{*}{$\begin{array}{c}\text { Alternative } \\
\text { oxidase } \\
(a o)\end{array}$} & \multirow{3}{*}{ SW1 F } & \multirow{4}{*}{ TGCCTGCACCGGCTATTG } & \multirow{6}{*}{90} & D1 & 15276.1 & 1.0 \\
\hline & & & & & D2 & 14721.9 & 0.9 \\
\hline & & & & & D3 & 41355.4 & 2.7 \\
\hline & & \multirow{3}{*}{ SW1 R } & & & ID1 & 10470.2 & 1.0 \\
\hline & & & \multirow[t]{2}{*}{ CTTCATCAGCACGGACCACC } & & ID2 & 16953.3 & 1.6 \\
\hline & & & & & ID3 & 16082.7 & 1.5 \\
\hline \multirow{6}{*}{2} & \multirow{6}{*}{$\begin{array}{l}\text { LEA } \\
\text { family } \\
\text { protein } \\
\text { (lea) }\end{array}$} & \multirow{3}{*}{ SW2 F } & \multirow{3}{*}{$\begin{array}{c}\text { GAGAAGGGAAGCGAAGTGG } \\
\text { G }\end{array}$} & \multirow{6}{*}{145} & D1 & 1067.8 & 1.0 \\
\hline & & & & & D2 & 5635.8 & 5.2 \\
\hline & & & & & D3 & 79284.9 & 74.2 \\
\hline & & \multirow{3}{*}{ SW2 R } & \multirow{3}{*}{$\begin{array}{c}\text { ACTCCGAAGCAAACTGAGC } \\
\text { A }\end{array}$} & & ID1 & 1994.9 & 1.0 \\
\hline & & & & & ID2 & 3952.5 & 1.9 \\
\hline & & & & & ID3 & 951.8 & 0.4 \\
\hline \multirow{6}{*}{3} & \multirow{6}{*}{$\begin{array}{l}\text { Cytochrom } \\
\text { e } \\
\text { P-450 } \\
\text { (cytp450) }\end{array}$} & \multirow{3}{*}{ SW3 F } & \multirow{3}{*}{ AAGAGTCGGCTTACGAGCTG } & \multirow{6}{*}{110} & D1 & 39.6 & 1.0 \\
\hline & & & & & $\mathrm{D} 2$ & 41.8 & 1.0 \\
\hline & & & & & D3 & 81.1 & 2.0 \\
\hline & & \multirow{3}{*}{ SW3 R } & \multirow{3}{*}{$\begin{array}{c}\text { CTTGGGGCTGAAGAGATGG } \\
\text { G }\end{array}$} & & ID1 & 73.9 & 1.0 \\
\hline & & & & & ID2 & 26.9 & 0.3 \\
\hline & & & & & ID3 & 34.5 & 0.4 \\
\hline 4 & ATP & SW4 F & GGATGAGCCAACTTCAGGCT & 82 & D1 & 407.7 & 1.0 \\
\hline
\end{tabular}




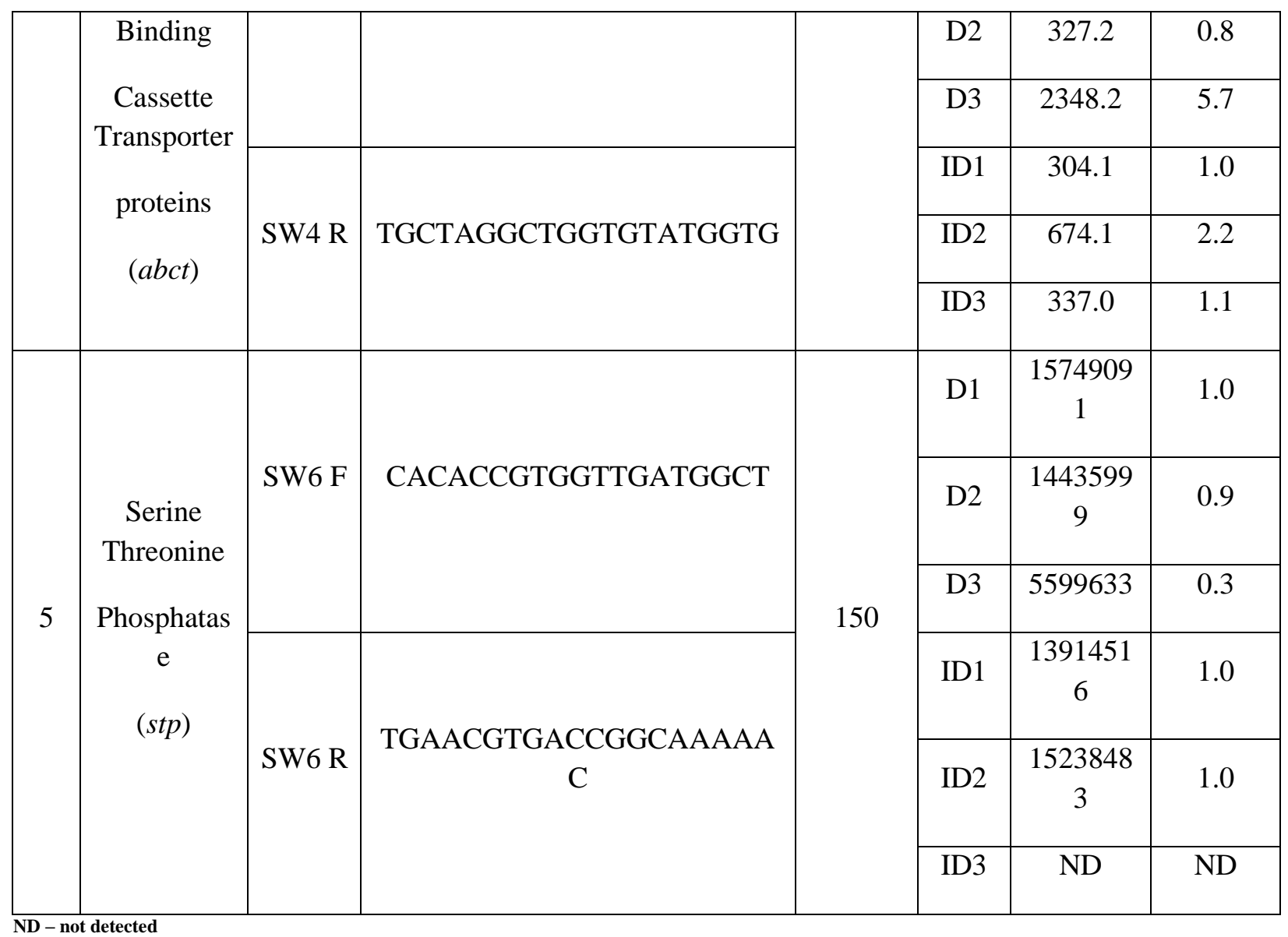

Alternative oxidase (ao)

Alternative oxidase (ao) is ubiquitous protein in all plants which play role in stress response, in addition, major contribution in regulating cellular thermodynamic responses by alteration of radicals (Van Aken et al. 2009). Relative gene expression pattern of ao observed during direct and indirect organogenesis as depicted in Figure 2a. During direct organogenesis, gene expression remained nearly consistent in terms of transcript copy number from inoculated leaf to proliferated leaf. This can be amenable with the report by Millenaar and Lambers (2003) where the excess production of reactive oxygen species free radicals was controlled by ao by continuing the citric acid cycle and regulating mitochondrial ubiquitin pool.

Indirect organogenesis was induced by different doses of 2,4-D phytohormone which act as a stress growth regulator that forms the unorganized mass called callus (Ikeuchi 2013 and Tahir et al. 2011). During indirect organogenesis, increase in gene expression was visualized from inoculated leaf to leaf proliferation stage. This indicate that alternative oxidase capacity for the storage of carbohydrates may have increased as mentioned by Steingrover 1981; Lambers et al. (1981). Linus et al. (1983) stated functions of $a o$ as a reserve electron transport capacity in callus in which cytochrome pathway activity was impaired. Further, expression remained consistent in callus induction phase. Noteworthy point was that the next stages of shoot 
formation through indirect organogenesis showed reduction in transcript level as $a o$ as illustrated by Lambers (1980). The ao disproportionate curve indicates that $a o$ set the defense equilibrium or threshold in plant cells, in the absence of which plants showed irregularity in growth pattern and responded abruptly to stress as noticed in indirect organogenesis under stress condition induced by 2, 4-D (Fiorani. 2005).

\section{Late embryogenesis abundant (lea)}

Late embryogenesis abundant (lea) are low molecular weight (10-30 kDa) proteins which mainly involved in protecting higher plants from damage caused by environmental stresses, especially drought (dehydration). The expression of lea gene had increased from 1.0 (inoculated leaf stage) to 5.2-fold (proliferated one) and sudden up-regulation (74.2-fold) was observed at shoot formation stage during direct organogenesis.

However, in case of indirect organogenesis lea expression reached its peak from 1.0 (leaf inoculation) to 1.9 (leaf proliferation stage) followed by sharp decline (0.4) at callus formation stage (Figure 2b). Looking at the fold change value of lea during direct and indirect organogenesis, the level of expression increased to 2-3 fold, from inoculated leaf to proliferated leaf stage but at the time of shoot formation/callusing, the value increased to 70 fold higher and to approximately half during direct and indirect organogenesis, respectively. Such expression pattern of lea during indirect organogenesis indicated the vital role in differentiated tissue rather than undifferentiated one. For survival, higher plants acclimatize themselves to changing environment through various mechanisms involved at different levels. The present report also deduced coherent results which stated that due to stress in shooting stage of direct organogenesis, the expression of lea had been significantly higher due to high signal transduction. However during indirect organogenesis, the stress response was negligible and therefore the low transcript profiling was detected. Gao and Lan (2016) reported late embryogenesis abundant (lea) proteins as a large and highly diverse gene family in pines that played a vital role not only in various stress tolerance responses but also crucial during embryonic development. This was evident during direct organogenesis where the transcript copy number was significantly high from inoculated leaf to leaf proliferation stage whereas during indirect organogenesis the expression declined as compared to normal developmental levels.

Cytochrome p-450 (cyt-p450)

To better understand the organogenesis events, another gene expression pattern of Cytochrome P-450 was included. Like ao, cyt-p450 showed insignificant change in expression 
during first two stages of direct organogenesis and then doubled at shoot formation stage while in indirect organogenesis continuous down-regulation pattern was observed (Figure 2c). The double number of transcripts at shoots formation stage in direct organogenesis pathway have been obtained due to regulation of auxin biosynthesis by cytochrome 450 family proteins which ultimately affected the growth and development of the plant as explained by Bak and Feyereisen (2001) and Vadassery et al. (2008) in Arabidopsis plant. Further, the cytochrome p-450 and alternative oxidases pathways were interlinked and differed reciprocally highlighting the simultaneous decrease in cytochrome p-450 with ascending alternative oxidases expression during indirect organogenesis which was in account of studies by Bahr and Bonner (1973) and Theologis and Laties (1978).

\section{ATP Binding Cassette Transporter Proteins (abct)}

The abct gene revealed the down regulation during direct organogenesis from inoculated leaf to leaf proliferation. However, almost six fold up regulation was observed at shoot formation stage. This finding clearly indicated that as the plant attained maturity, the transcript level has increased. Gaedeke et al. (2001) also postulated that abct is involved in stomata formation and expressed mainly in vascular bundles, epidermis especially in guard cells. It also works as auxin conjugate transporters that regulate auxin as well as ion channels. However, in case of callus mediated organogenesis two fold increase was observed during leaf proliferation stage and the level reached to its ground state, near to control, afterwards (Figure 3a). Kang et al. (2011), while working on Arabidopsis, also obtained similar expression patterns due to cellular detoxification processes that are necessary for organ growth, plant nutrition, plant development.

In agreement with the supporting literatures (Rea 2007; Schulz and Kolukisaoglu 2006; Theodoulou 2000), our analysis revealed a sharp up regulation at shoot formation stage during direct organogenesis contributed to the fact that plant at this stage require more ion transport, has high detoxification rate, and performs frequent stomata activity resulting in intense increase in $a b c t$ transcript level. Furthermore, the decline in $a b c t$ level at callus induction stages in indirect pathway revealed that the rate of stomata activity might have declined and as a result cell growth rate was affected as compared to normal. In conclusion, our curiosity led to prediction of $a b c t$ proteins regulation successfully which clearly differentiated the direct and indirect organogenesis event, visually contradict expression pattern at different pathway.

\section{Serine Threonine Phosphatase (stp)}

Serine/threonine protein phosphatases plays critical role in the regulation of cell cycle. In the present study constant down regulation of stp was observed during both direct and indirect pathways (Figure 3b). 


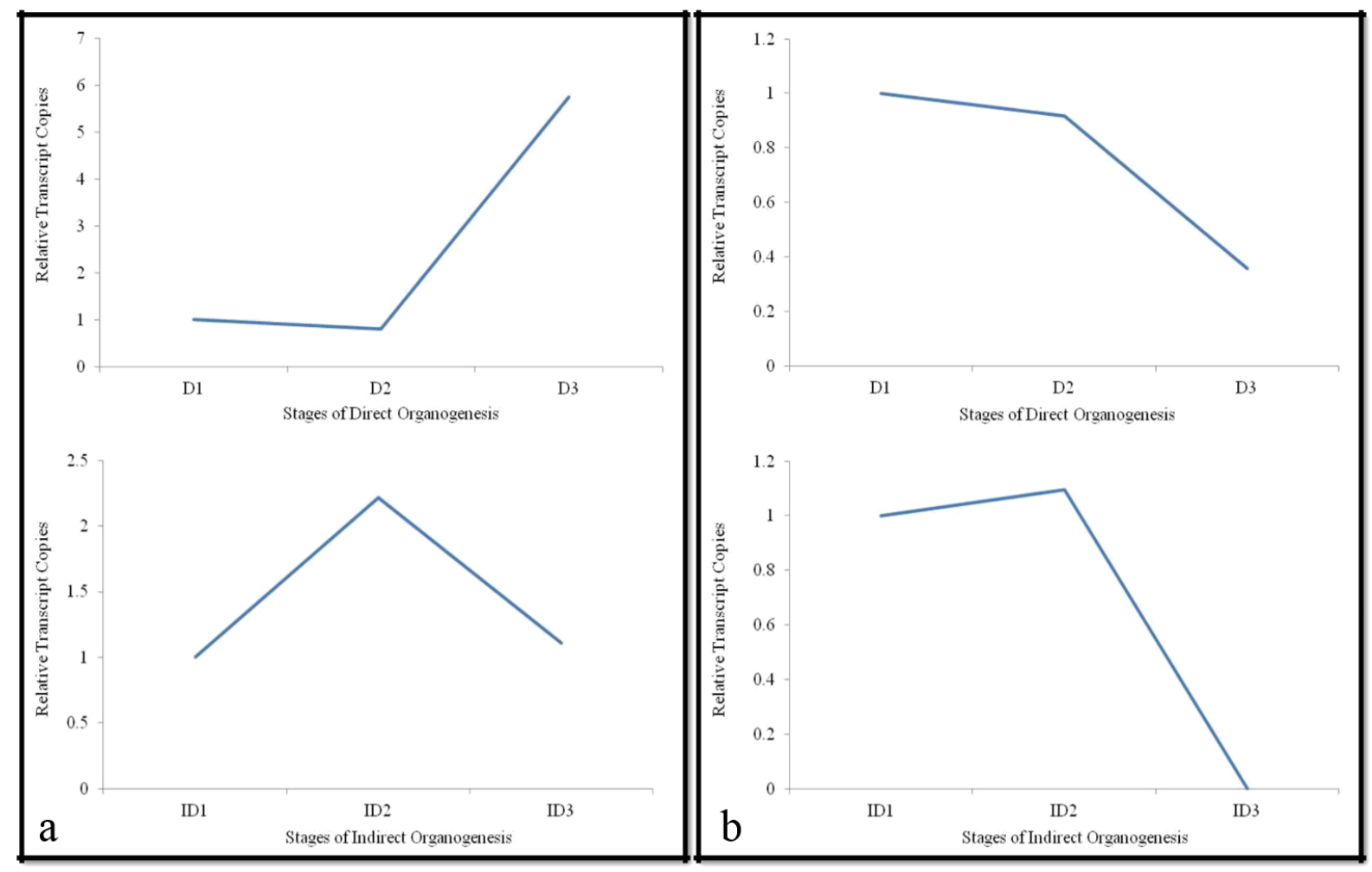

Fig. 3: Relative gene expression pattern of abct (a); and spt (b) within three stages of direct and indirect organogenesis. D1 - inoculated leaf, D2 - proliferated leaf and D3 - shoot formation stage, ID1 - inoculated leaf, ID2 - proliferated leaf and ID3 - callus formation.

The continuous decline in expression during direct organogenesis might be due to the ability of okadaic acid to activate other transcription factors which caused alteration in protein serine/threonine resulting in dephosphorylation as explained by Mumby and G. Walter (1993). Whilst, during indirect organogenesis, the transcript copy number did not change initially but sharply delineated to zero at callusing stage which marked the central role of protein serine/threonine phosphatase in the re-entry of quiescent cells into the cell cycle. This re-entry suggested the dedifferentiated phase of callus that may trigger the cell for redifferentiation resulting in increase in the mRNA level initially which further did not show any expression pattern as described by Villafranca (1996). The available information on the specific functions of different forms of protein serine/threonine phosphatases is still severely limited as mentioned by Mumby and Walter (1993).

From the above results and discussions, we anticipate the gene expression pattern can be used as a diagnostic tool for identification of different developmental stages in sandalwood. The combinations of gene expression patterns provides a potential information required for developmental stage identification. To widen our understanding about molecular aspects, the 
futher understanding of plant quantitative traits that are controlled by many genes and intricate pathways is essential.

\section{Conclusion}

In conclusion, out of five genes used to obtain gene expression patterns, three of them, namely; ao, cyt-p450 and stp showed little/no change in transcript copy number during initial two stages while two of these genes $a o$ and cyt-p450 showed up-regulation and stp showed down-regulation in direct pathway. Expression patterns of lea and abct showed strong molecular signature to predict the route of the organogenesis in sandalwood micropropagation as they were constantly up regulated during direct organogenesis and down regulated during indirect organogenesis. Thus the objective of the present investigation had come to the fulfillment with the help of dynamic expression patterns of lea and abct during initial stages of organogenesis and it is now clear that one can predict the fate of explant.

\section{References}

Adesoye A, Orkpeh, U (2009) Effect of plant growth regulator, light and media formulation on initiation and growth of Parkia biglobosa (Jacq.) R. Br. Ex Don callus cultures from cotyledons and mature zygotic embryos. Nigerian Journal of Horticultural Science 14(1):67-75. https://doi.org/10.4314/njhs.v14i1.62160

Bahr JT, Bonner WD (1973) Cyanide-insensitive respiration II. Control of the alternate pathway. J Biol Chem 248(10):3446-3450.

Bak S, Feyereisen R (2001) The involvement of two P450 enzymes, CYP83B1 and CYP83A1, in auxin homeostasis and glucosinolate biosynthesis. Pl Physiol 127(1):108-118. https://doi.org/10.1104/pp.127.1.108

Behbahani M, Shanehsazzadeh M, Hessami MJ (2011) Optimization of callus and cell suspension cultures of Barringtonia racemosa (Lecythidaceae family) for lycopene production. Scientia Agricola 68(1):69-76. https://doi.org/10.1590/S0103-90162011000100011

Che P, Lall S, Nettleton D, Howell SH (2006) Gene expression programs during shoot, root, and callus development in Arabidopsis tissue culture. Pl Physiol 141(2):620-637. https://doi.org/10.1104/pp.106.081240

Fiorani F, Umbach AL, Siedow JN (2005) The alternative oxidase of plant mitochondria is involved in the acclimation of shoot growth at low temperature. A study of Arabidopsis AOX1a transgenic plants. Pl Physiol 139(4):1795-1805. https://dx.doi.org/10.1104\%2Fpp.105.070789 
Freeman TC, Lee K, Richardson PJ (1999) Analysis of gene expression in single cells. Curr Opin Biotech 10(6):579-582. https://doi.org/10.1016/S0958-1669(99)00036-1

Gaedeke N, Klein M, Kolukisaoglu U, Forestier C, Müller A, Ansorge M, Becker D, Mamnun Y, Kuchler K, Schulz B Mueller-Roeber B (2001) The Arabidopsis thaliana ABC transporter AtMRP5 controls root development and stomata movement. EMBO J 20(8):1875-1887. https://dx.doi.org/10.1093\%2Femboj\%2F20.8.1875

Ghawana S, Paul A, Kumar H, Kumar A, Singh H, Bhardwaj PK, et al (2011) An RNA isolation system for plant tissues rich in secondary metabolites. BMC Res Notes 4(1):pp.1-5. https://doi.org/10.1186/1756-0500-4-85

Ikeuchi M, Sugimoto K Iwase A (2013) Plant callus: mechanisms of induction and repression. The Plant Cell 25(9):3159-3173. https://doi.org/10.1105/tpc.113.116053 Jain SM, Minocha SC (2013) Molecular biology of woody plants (Vol. 1). Springer, Netherlands

Kumar AA, Joshi G, Ram HM (2012) Sandalwood: history, uses, present status and the future. Curr Sci 25:1408-1416.

Lambers H (1980) The physiological significance of cyanide-resistant respiration in higher plants. Plant Cell Environ 3(5):293-302. https://doi.org/10.1111/1365-3040.ep11581846

Lambers H, Atkin OK, Millenaar FF (1996) Respiratory patterns in roots in relation to their functioning. In: Waisel Y, Eshel A, Kafkaki U (Eds) Plant roots. The hidden half 3rd edn. Marcel Dekker Inc., New York, pp 521-552.

Lambers H, Blacquière T, Stuiver B (1981) Interactions between osmoregulation and the alternative respiratory pathway in Plantago coronopus as affected by salinity. Physiol Plant 51(1):63-68. https://doi.org/10.1111/j.1399-3054.1981.tb00880.x

Linus HW, Wagner MJ (1983) Regulation of the activity of the alternative oxidase in callus forming discs from potato tubers. Physiol Plant 58(3):311-317. https://doi.org/10.1111/j.13993054.1983.tb04186.x

Lloyd G, McCown B (1980) Commercially-feasible micropropagation of mountain laurel, Kalmia latifolia, by use of shoot-tip culture. Commercially-feasible micropropagation of mountain laurel, Kalmia latifolia, by use of shoot-tip culture 30:421-427.

Mackay IM, Arden KE, Nitsche A (2002) Real-time PCR in virology. Nucleic Acids Res 30(6):1292-1305. https://dx.doi.org/10.1093\%2Fnar\%2F30.6.1292

Millenaar FF, Lambers H (2003) The alternative oxidase: in vivo regulation and function. Plant Biol 5(1):2-15. https://doi.org/10.1055/s-2003-37974 
Mujib A (2005) In vitro regeneration of sandal (Santalum album L.) from leaves. Turk J Bot 29(1):63-67.

Mumby MC, Walter G (1993) Protein serine/threonine phosphatases: structure, regulation, and

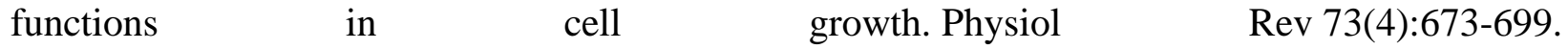
https://doi.org/10.1152/physrev.1993.73.4.673

Rashmi R, Trivedi MP (2014) Effect of various growth hormone concentration and combination on callus induction, nature of callus and callogenic response of Nerium odorum. Appl Biochem Biotechnol 172(5):2562-2570. https://doi.org/10.1007/s12010-013-0693-1

Rea PA (2007) Plant ATP-binding cassette transporters. Annu Rev Plant Biol 58:347-375. https://doi.org/10.1146/annurev.arplant.57.032905.105406

Rugkhla A, Jones MGK (1998) Somatic embryogenesis and plantlet formation in Santalum album and S. spicatum. J Exp Bot 49(320):563-571. https://doi.org/10.1093/jxb/49.320.563

Schulz B, Kolukisaoglu HU (2006) Genomics of plant ABC transporters: the alphabet of photosynthetic life forms or just holes in membranes?. FEBS Letters 580(4):1010-1016. https://doi.org/10.1016/j.febslet.2006.01.002

Singh CK, Raj SR, Patil VR, Jaiswal PS, Subhash N (2013) Plant regeneration from leaf explants of mature sandalwood (Santalum album L.) trees under in vitro conditions. In Vitro Cell Develop Biol Plant 49(2):216-222. https://doi.org/10.1007/s11627-013-9495-y

Steingrover E (1981) The relationship between cyanide-resistant root respiration and the storage of sugars in the taproot in Daucus carota L. J Exp Bot 32(5):3911-919. https://doi.org/10.1093/jxb/32.5.911

Steuerwald N, Cohen JJ, Herrera R, Brenner C (1999) Analysis of gene expression in single oocytes and embryos by real-time rapid cycle fluorescence monitored RT-PCR. Mol Hum Reprod 5(11):1034-1039. https://doi.org/10.1093/molehr/5.11.1034

Subasinghe SMCUP (2013) Sandalwood research: a global perspective. Journal of Tropical Forestry and Environment, 3(1), pp.1-8. https://doi.org/10.13140/2.1.2548.5445

Tahir SM, Victor K, Abdulkadir S (2011) The effect of 2, 4-Dichlorophenoxy acetic acid (2, 4D) concentration on callus induction in sugarcane (Saccharum officinarum). Nigerian Journal of Basic and Applied Sciences 19(2):213-217. https://www.ajol.info/index.php/njbas/article/view/73846

Theodoulou FL (2000) Plant ABC transporters. Biochimica et Biophysica Acta (BBA)Biomembranes 1465(1-2):79-103. https://doi.org/10.1016/s0005-2736(00)00132-2 
Theologis A, Laties GG (1978) Cyanide-resistant respiration in fresh and aged sweet potato slices. Pl Physiol 62(2):243-248. https://doi.org/10.1104/pp.62.2.243

Thorpe T.A. (1990) Organogenesis: Structural, Physiological and Biochemical Aspects. In: Rodríguez R., Tamés R.S., Durzan D.J. (eds) Plant Aging. NATO ASI Series (Series A: Life Sciences), vol 186. Springer, Boston, MA. https://doi.org/10.1007/978-1-4684-5760-5_23

Vadassery J, Ritter C, Venus Y et al (2008) The role of auxins and cytokinins in the mutualistic interaction between Arabidopsis and Piriformospora indica. Mol Plant Microb Interact 21(10):1371-1383. https://doi.org/10.1094/mpmi-21-10-1371

Van Aken O, Giraud E, Clifton R, Whelan J (2009) Alternative oxidase: a target and regulator of stress responses. Physiol Plant 137(4):354-361. https://doi.org/10.1111/j.13993054.2009.01240.x 

Supplementary Table 1 Direct organogenesis - Morphology of the shoot buds derived from the defoliated leaf explant at the end of 40, 80 and 120 days

\begin{tabular}{|c|c|c|c|c|c|c|c|c|c|c|c|c|}
\hline \multirow[b]{2}{*}{$\begin{array}{l}\text { Media } \\
\text { code }\end{array}$} & \multicolumn{2}{|c|}{ PGRs } & \multicolumn{2}{|c|}{ After 40 days } & \multicolumn{4}{|c|}{ After 80 days } & \multicolumn{4}{|c|}{ After 120 days } \\
\hline & $\begin{array}{l}\text { BAP } \\
\underset{1}{\left(\mathbf{m g l}^{-}\right.}\end{array}$ & $\begin{array}{l}\text { NAA } \\
\left(\begin{array}{c}\mathbf{m g l}^{-} \\
\mathbf{1}^{-}\end{array}\right.\end{array}$ & $\begin{array}{c}\text { Bud } \\
\text { Frequency } \\
(\%)\end{array}$ & $\begin{array}{c}\text { Health } \\
\text { range }\end{array}$ & $\begin{array}{c}\text { Area } \\
\text { covered by } \\
\text { bud } \\
\text { sprouting } \\
(\%)\end{array}$ & $\begin{array}{l}\text { Number } \\
\text { of shoots }\end{array}$ & $\begin{array}{l}\text { Length } \\
\text { of shoots } \\
(\mathrm{cm})\end{array}$ & $\begin{array}{c}\text { Health } \\
\text { range }\end{array}$ & $\begin{array}{c}\begin{array}{c}\text { covered by } \\
\text { bud } \\
\text { sprouting }\end{array} \\
(\%)\end{array}$ & $\begin{array}{l}\text { Number } \\
\text { of shoots }\end{array}$ & $\begin{array}{c}\text { Length } \\
\text { of shoots } \\
(\%)\end{array}$ & $\begin{array}{c}\text { Health } \\
\text { range }\end{array}$ \\
\hline $\mathrm{SD}_{1}$ & 0.0 & 0.0 & $0.00^{\mathrm{f}}$ & + & $0.00^{\mathrm{t}}$ & $0.00^{\mathrm{a}}$ & $0.00^{\mathrm{g}}$ & + & $0.00^{\mathrm{h}}$ & $0.00^{\mathrm{f}}$ & $0.00^{\mathrm{t}}$ & + \\
\hline $\mathrm{SD}_{2}$ & 1.0 & 0.0 & $0.00^{\mathrm{f}}$ & + & $5.00^{\mathrm{h}}$ & $1.00^{\mathrm{a}}$ & $0.30^{\mathrm{f}}$ & + & $10.00^{\mathrm{g}}$ & $2.00^{\mathrm{d}}$ & $0.70^{\mathrm{t}}$ & + \\
\hline $\mathrm{SD}_{3}$ & 1.5 & 0.0 & $0.00^{f}$ & ++ & $10.00^{\mathrm{fg}}$ & $1.00^{\mathrm{a}}$ & $0.40^{\mathrm{f}}$ & ++ & $20.00^{f}$ & $2.25^{\mathrm{d}}$ & $1.00^{\mathrm{h}}$ & ++ \\
\hline $\mathrm{SD}_{4}$ & 2.0 & 0.0 & $0.00^{f}$ & ++ & $8.75^{\mathrm{g}}$ & $1.00^{\mathrm{a}}$ & $0.50^{\mathrm{f}}$ & ++ & $20.00^{f}$ & $2.75^{\mathrm{c}}$ & $1.50^{\mathrm{g}}$ & ++ \\
\hline $\mathrm{SD}_{5}$ & 2.5 & 0.0 & $0.00^{\mathrm{f}}$ & ++ & $12.50^{\mathrm{f}}$ & $2.00^{\mathrm{a}}$ & $1.00^{\mathrm{d}}$ & ++ & $20.00^{\mathrm{f}}$ & $4.00^{\mathrm{b}}$ & $2.00^{\mathrm{fe}}$ & ++ \\
\hline $\mathrm{SD}_{6}$ & 0.0 & 0.2 & $0.00^{f}$ & ++ & $0.00^{t}$ & $0.00^{\mathrm{a}}$ & $0.00^{\mathrm{g}}$ & ++ & $0.00^{\mathrm{h}}$ & $0.00^{f}$ & $0.00^{\mathrm{j}}$ & ++ \\
\hline $\mathrm{SD}_{7}$ & 1.0 & 0.2 & $7.50^{f}$ & +++ & $52.50^{\mathrm{b}}$ & $3.00^{\mathrm{a}}$ & $1.75^{\mathrm{b}}$ & +++ & $67.50^{\mathrm{b}}$ & $5.00^{\mathrm{a}}$ & $2.75^{\mathrm{bc}}$ & +++ \\
\hline $\mathrm{SD}_{8}$ & 1.5 & 0.2 & $20.00^{c}$ & +++ & $30.00^{\mathrm{d}}$ & $1.00^{\mathrm{a}}$ & $1.00^{\mathrm{d}}$ & +++ & $40.00^{\mathrm{d}}$ & $2.00^{\mathrm{d}}$ & $2.25^{\mathrm{df}}$ & +++ \\
\hline $\mathrm{SD}_{9}$ & 2.0 & 0.2 & $10.00^{\mathrm{d}}$ & +++ & $40.00^{c}$ & $2.00^{\mathrm{a}}$ & $1.50^{c}$ & +++ & $47.50^{c}$ & $3.75^{\mathrm{b}}$ & $3.00^{\mathrm{b}}$ & +++ \\
\hline $\mathrm{SD}_{10}$ & 2.5 & 0.2 & $0.00^{f}$ & + & $0.00^{t}$ & $0.00^{\mathrm{a}}$ & $0.00^{\mathrm{g}}$ & + & $0.00^{\mathrm{h}}$ & $0.00^{\mathrm{f}}$ & $0.00^{\mathrm{t}}$ & + \\
\hline $\mathrm{SD}_{11}$ & 0.0 & 0.4 & $0.00^{\mathrm{f}}$ & + & $0.00^{t}$ & $0.00^{\mathrm{a}}$ & $0.00^{\mathrm{g}}$ & + & $0.00^{\mathrm{h}}$ & $0.00^{\mathrm{f}}$ & $0.00^{\mathrm{t}}$ & + \\
\hline $\mathrm{SD}_{12}$ & 1.0 & 0.4 & $0.00^{f}$ & + & $20.00^{f}$ & $1.00^{\mathrm{a}}$ & $0.50^{\mathrm{f}}$ & + & $30.00^{f}$ & $2.00^{\mathrm{d}}$ & $1.75^{\mathrm{fg}}$ & + \\
\hline $\mathrm{SD}_{13}$ & 1.5 & 0.4 & $20.00^{c}$ & +++ & $30.00^{\mathrm{d}}$ & $1.25^{\mathrm{a}}$ & $1.00^{\mathrm{d}}$ & +++ & $40.00^{\mathrm{d}}$ & $3.00^{c}$ & $2.00^{\mathrm{fe}}$ & +++ \\
\hline $\mathrm{SD}_{14}$ & 2.0 & 0.4 & $40.00^{\mathrm{a}}$ & ++++ & $60.00^{\mathrm{a}}$ & $3.00^{\mathrm{a}}$ & $2.00^{\mathrm{a}}$ & ++++ & $70.00^{\mathrm{a}}$ & $5.00^{\mathrm{a}}$ & $4.00^{\mathrm{a}}$ & ++++ \\
\hline $\mathrm{SD}_{15}$ & 2.5 & 0.4 & $30.00^{\mathrm{b}}$ & ++++ & $40.00^{c}$ & $2.00^{\mathrm{a}}$ & $1.50^{\mathrm{c}}$ & ++++ & $50.00^{c}$ & $4.00^{\mathrm{b}}$ & $2.50^{\mathrm{cd}}$ & ++++ \\
\hline \multirow{3}{*}{\multicolumn{3}{|c|}{$\begin{array}{l}\text { S.Em. } \\
\text { C.D. at } 5 \% \\
\text { C. V. \% }\end{array}$}} & 0.373 & & 0.968 & 1.92 & 0.037 & & 0.645 & 0.112 & 0.083 & \\
\hline & & & 1.065 & & 2.767 & 0.00 & 0.107 & & 1.845 & 0.320 & 0.238 & \\
\hline & & & 8.77 & & 9.41 & 0.00 & 9.36 & & 4.64 & 8.89 & 9.82 & \\
\hline
\end{tabular}

All the treatments were analyzed by DNMRT and treatment means with same letters were at par at $5 \%$ level of significance.

PGRs - Plant Growth Regulators. + Poor, ++ Moderate, +++ Healthy, ++++ Very healthy. 
Supplementary Table 2 Indirect organogenesis - Morphology of the callus derived from the defoliated leaf explant at the end of 40,80 and 120 days

\begin{tabular}{|c|c|c|c|c|c|c|c|c|c|c|c|c|c|c|c|c|c|c|c|c|c|c|}
\hline \multirow[b]{2}{*}{$\begin{array}{c}\text { Media } \\
\text { Code }\end{array}$} & \multicolumn{6}{|c|}{ PGRs } & \multicolumn{6}{|c|}{ After 40 days } & \multicolumn{5}{|c|}{ After 80 days } & \multicolumn{5}{|c|}{ After 120 days } \\
\hline & $\begin{array}{c}\text { BAP } \\
(\mathbf{m g l}- \\
\text { 1) }\end{array}$ & $\begin{array}{c}\begin{array}{c}2,4- \\
\text { D } \\
(\mathbf{m g l} \\
1)\end{array} \\
\end{array}$ & $\begin{array}{c}\text { Glycine } \\
\left(\text { mgl }^{-1}\right)\end{array}$ & $\begin{array}{c}\mathrm{ADS} \\
(\mathbf{m g l} \\
1)\end{array}$ & $\begin{array}{l}\mathrm{KNO}_{3} \\
\left(\mathbf{m g l}^{-1}\right)\end{array}$ & $\begin{array}{c}\text { NAA } \\
(\mathbf{m g l} \\
1)\end{array}$ & $\begin{array}{c}\text { Days to } \\
\text { callus } \\
\text { induction }\end{array}$ & $\begin{array}{c}\text { Callus } \\
\text { induction } \\
(\%)\end{array}$ & $\begin{array}{c}\text { Callus } \\
\text { frequency } \\
(\%)\end{array}$ & $\begin{array}{c}\text { Callus } \\
\text { type }\end{array}$ & $\begin{array}{l}\text { Callus } \\
\text { colour }\end{array}$ & $\begin{array}{l}\text { Health } \\
\text { range }\end{array}$ & $\begin{array}{c}\text { Callus } \\
\text { induction } \\
(\%)\end{array}$ & $\begin{array}{c}\text { Callus } \\
\text { frequency } \\
(\%)\end{array}$ & $\begin{array}{c}\text { Callus } \\
\text { type }\end{array}$ & $\begin{array}{l}\text { Callus } \\
\text { colour }\end{array}$ & $\begin{array}{l}\text { Health } \\
\text { range }\end{array}$ & $\begin{array}{c}\text { Callus } \\
\text { Induction } \\
(\%)\end{array}$ & $\begin{array}{c}\text { Callus } \\
\text { regeneration } \\
\text { frequency } \\
(\%)\end{array}$ & $\begin{array}{c}\text { Callus } \\
\text { type }\end{array}$ & $\begin{array}{l}\text { Callus } \\
\text { colour }\end{array}$ & $\begin{array}{l}\text { Health } \\
\text { range }\end{array}$ \\
\hline $\mathrm{SI}_{1}$ & 0.0 & 0.0 & - & - & - & - & $0.00^{h}$ & $0.00^{\mathrm{g}}$ & $0.00^{\mathrm{g}}$ & NR & ND & + & $0.00^{\mathrm{h}}$ & $0.00^{\mathrm{h}}$ & NR & $\mathrm{ND}$ & + & $0.00^{\mathrm{h}}$ & $0.00^{\mathrm{t}}$ & NR & ND & + \\
\hline $\mathrm{SI}_{2}$ & 0.0 & 1.0 & - & - & - & - & $0.00^{h}$ & $0.00^{\mathrm{g}}$ & $0.00^{\mathrm{g}}$ & NR & ND & + & $0.00^{h}$ & $0.00^{h}$ & NR & ND & + & $0.00^{h}$ & $0.00^{t}$ & NR & ND & + \\
\hline $\mathrm{SI}_{3}$ & 0.5 & 1.0 & - & - & - & - & $0.00^{\mathrm{h}}$ & $0.00^{\mathrm{g}}$ & $0.00^{\mathrm{g}}$ & NR & ND & + & $0.00^{\mathrm{h}}$ & $0.00^{\mathrm{h}}$ & NR & ND & + & $0.00^{\mathrm{h}}$ & $0.00^{t}$ & NR & ND & + \\
\hline $\mathrm{SI}_{4}$ & 1.0 & 1.0 & - & - & - & - & $0.00^{\mathrm{h}}$ & $0.00^{\mathrm{g}}$ & $0.00^{\mathrm{g}}$ & NR & ND & + & $0.00^{\mathrm{h}}$ & $0.00^{\mathrm{h}}$ & NR & ND & + & $0.00^{\mathrm{h}}$ & $0.00^{t}$ & NR & ND & + \\
\hline $\mathrm{SI}_{5}$ & 0.0 & 2.0 & - & - & - & - & $37.00^{\mathrm{a}}$ & $20.00^{f}$ & $5.00^{\mathrm{f}}$ & $\mathrm{F}$ & $\mathrm{G}$ & +++ & $10.00^{\mathrm{g}}$ & $40.00^{\mathrm{d}}$ & $\mathrm{F}$ & $\mathrm{G}$ & +++ & $20.00^{\mathrm{g}}$ & $50.00^{\mathrm{f}}$ & $\mathrm{F}$ & $\mathrm{G}$ & +++ \\
\hline $\mathrm{SI}_{6}$ & 0.5 & 2.0 & - & - & - & - & $37.00^{\mathrm{a}}$ & $10.00^{\mathrm{f}}$ & $10.00^{\mathrm{f}}$ & $\mathrm{F}$ & $\mathrm{G}$ & +++ & $20.00^{f}$ & $30.00^{\mathrm{f}}$ & $\mathrm{F}$ & G & +++ & $30.00^{\mathrm{ef}}$ & $40.00^{\mathrm{f}}$ & $\mathrm{F}$ & $\mathrm{G}$ & +++ \\
\hline $\mathrm{SI}_{7}$ & 1.0 & 2.0 & - & - & - & - & $37.00^{\mathrm{a}}$ & $10.00^{\mathrm{f}}$ & $10.00^{\mathrm{f}}$ & $\mathrm{F}$ & $\mathrm{Y}$ & +++ & $30.00^{\mathrm{d}}$ & $20.00^{\mathrm{g}}$ & $\mathrm{F}$ & $\mathrm{Y}$ & +++ & $40.00^{\mathrm{d}}$ & $30.00^{\mathrm{h}}$ & $\mathrm{F}$ & $\mathrm{Y}$ & +++ \\
\hline $\mathrm{SI}_{8}$ & 0.5 & 2.5 & - & - & - & - & $35.00^{\mathrm{g}}$ & $20.00^{f}$ & $20.00^{\mathrm{d}}$ & $\mathrm{F}$ & $\mathrm{G}$ & +++ & $20.00^{f}$ & $20.00^{\mathrm{g}}$ & $\mathrm{F}$ & $\mathrm{G}$ & +++ & $30.00^{\mathrm{ef}}$ & $32.50^{\mathrm{gh}}$ & $\mathrm{F}$ & $\mathrm{G}$ & +++ \\
\hline $\mathrm{SI}_{9}$ & 0.0 & 2.5 & - & - & - & - & $36.00^{\mathrm{df}}$ & $10.00^{f}$ & $20.00^{\mathrm{d}}$ & $\mathrm{C}$ & $\mathrm{G}$ & +++ & $30.00^{\mathrm{d}}$ & $20.00^{\mathrm{g}}$ & $\mathrm{C}$ & $\mathrm{G}$ & +++ & $50.00^{c}$ & $30.00^{\mathrm{h}}$ & $\mathrm{C}$ & $\mathrm{G}$ & +++ \\
\hline $\mathrm{SI}_{10}$ & 1.0 & 2.5 & - & - & - & - & $36.25^{\mathrm{cd}}$ & $20.00^{f}$ & $20.00^{\mathrm{d}}$ & $\mathrm{C}$ & $\mathrm{Y}$ & +++ & $20.00^{f}$ & $30.00^{\mathrm{f}}$ & $\mathrm{C}$ & $\mathrm{Y}$ & +++ & $40.00^{\mathrm{d}}$ & $40.00^{f}$ & $\mathrm{C}$ & $\mathrm{Y}$ & +++ \\
\hline $\mathrm{SI}_{11}$ & 0.0 & 5.0 & - & - & - & - & $37.00^{\mathrm{a}}$ & $30.00^{c}$ & $5.00^{\mathrm{f}}$ & $\mathrm{C}$ & $\mathrm{G}$ & +++ & $10.00^{\mathrm{g}}$ & $30.00^{\mathrm{f}}$ & $\mathrm{C}$ & $\mathrm{G}$ & +++ & $22.50^{\mathrm{g}}$ & $40.00^{\mathrm{f}}$ & $\mathrm{C}$ & $\mathrm{G}$ & +++ \\
\hline $\mathrm{SI}_{12}$ & 0.5 & 5.0 & - & - & - & - & $36.75^{\mathrm{ab}}$ & $20.00^{f}$ & $5.00^{\mathrm{f}}$ & $\mathrm{F}$ & $\mathrm{G}$ & +++ & $10.00^{\mathrm{g}}$ & $32.50^{\mathrm{f}}$ & $\mathrm{F}$ & $\mathrm{G}$ & +++ & $27.50^{f}$ & $42.50^{\mathrm{f}}$ & $\mathrm{F}$ & $\mathrm{G}$ & +++ \\
\hline $\mathrm{SI}_{13}$ & 1.0 & 5.0 & - & - & - & - & $36.50^{\mathrm{bc}}$ & $10.00^{f}$ & $10.00^{\mathrm{f}}$ & $\mathrm{F}$ & $\mathrm{Y}$ & +++ & $20.00^{f}$ & $20.00^{\mathrm{g}}$ & $\mathrm{F}$ & $\mathrm{Y}$ & +++ & $30.00^{\mathrm{ef}}$ & $30.00^{\mathrm{h}}$ & $\mathrm{F}$ & $\mathrm{Y}$ & +++ \\
\hline $\mathrm{SI}_{14}$ & - & - & 1.0 & - & - & - & $35.50^{f}$ & $10.00^{f}$ & $5.00^{\mathrm{f}}$ & $\mathrm{F}$ & $\mathrm{G}$ & +++ & $10.00^{\mathrm{g}}$ & $32.50^{\mathrm{f}}$ & $\mathrm{F}$ & $\mathrm{G}$ & +++ & $27.50^{f}$ & $40.00^{f}$ & $\mathrm{~F}$ & $\begin{array}{c}\mathrm{G} \\
+\mathrm{Y}\end{array}$ & +++ \\
\hline $\mathrm{SI}_{15}$ & - & - & 1.0 & 25 & - & - & $36.75^{\mathrm{ab}}$ & $27.50^{\mathrm{d}}$ & $5.00^{f}$ & $\mathrm{~F}$ & $\mathrm{G}$ & +++ & $20.00^{f}$ & $42.50^{\mathrm{d}}$ & $\mathrm{F}$ & G & +++ & $30.00^{\mathrm{ef}}$ & $50.00^{\mathrm{f}}$ & $\mathrm{F}$ & $\begin{array}{c}\mathrm{G}+ \\
\mathrm{Y}\end{array}$ & +++ \\
\hline $\mathrm{SI}_{16}$ & - & - & 1.0 & 25 & - & - & $36.50^{\mathrm{bc}}$ & $10.00^{f}$ & $10.00^{\mathrm{f}}$ & $\mathrm{F}$ & $\mathrm{G}$ & ++++ & $20.00^{f}$ & $30.00^{\mathrm{f}}$ & $\mathrm{F}$ & $\mathrm{G}$ & ++++ & $32.50^{f}$ & $42.50^{\mathrm{f}}$ & $\mathrm{C}$ & $\mathrm{G}$ & ++++ \\
\hline $\mathrm{SI}_{17}$ & - & 2.0 & 1.0 & - & - & - & $37.00^{\mathrm{a}}$ & $20.00^{f}$ & $20.00^{\mathrm{d}}$ & $\mathrm{F}$ & $\mathrm{G}$ & ++++ & $27.50^{f}$ & $25.00^{\mathrm{f}}$ & $\mathrm{F}$ & $\mathrm{G}$ & ++++ & $42.50^{\mathrm{d}}$ & $35.00^{\mathrm{g}}$ & $\mathrm{F}$ & $\mathrm{G}$ & ++++ \\
\hline $\mathrm{SI}_{18}$ & - & 3.0 & 1.0 & 25 & - & - & $35.00^{\mathrm{a}}$ & $50.00^{\mathrm{a}}$ & $20.00^{\mathrm{d}}$ & $\mathrm{F}$ & $\mathrm{G}$ & ++++ & $30.00^{\mathrm{d}}$ & $50.00^{c}$ & $\mathrm{~F}$ & $\mathrm{G}$ & ++++ & $42.50^{\mathrm{d}}$ & $62.50^{\mathrm{cd}}$ & $\mathrm{F}$ & $\mathrm{G}$ & ++++ \\
\hline $\mathrm{SI}_{19}$ & - & 2.0 & - & - & 630.0 & - & $37.00^{\mathrm{a}}$ & $30.00^{c}$ & $20.00^{\mathrm{d}}$ & $\mathrm{F}$ & $\mathrm{G}$ & ++++ & $30.00^{\mathrm{d}}$ & $50.00^{c}$ & $\mathrm{~F}$ & $\mathrm{G}$ & ++++ & $50.00^{c}$ & $52.50^{f}$ & $\mathrm{~F}$ & $\mathrm{G}$ & ++++ \\
\hline $\mathrm{SI}_{20}$ & - & 3.0 & - & - & - & - & $36.00^{\mathrm{g}}$ & $40.00^{\mathrm{b}}$ & $30.00^{c}$ & $\mathrm{~F}$ & $\mathrm{G}$ & +++ & $40.00^{c}$ & $67.50^{\mathrm{a}}$ & $\mathrm{F}$ & $\mathrm{G}$ & +++ & $52.50^{c}$ & $65.00^{\mathrm{c}}$ & $\mathrm{F}$ & $\mathrm{G}$ & +++ \\
\hline $\mathrm{SI}_{21}$ & - & 0.5 & - & - & - & - & $37.00^{\mathrm{a}}$ & $10.00^{f}$ & $5.00^{f}$ & $\mathrm{~F}$ & $\mathrm{G}$ & + & $10.00^{\mathrm{g}}$ & $20.00^{\mathrm{g}}$ & $\mathrm{F}$ & $\mathrm{G}$ & + & $20.00^{\mathrm{g}}$ & $30.00^{\mathrm{h}}$ & $\mathrm{F}$ & $\mathrm{G}$ & + \\
\hline $\mathrm{SI}_{22}$ & - & 1.0 & - & - & - & - & $36.00^{\mathrm{df}}$ & $10.00^{f}$ & $10.00^{f}$ & $\mathrm{~F}$ & $\mathrm{G}$ & ++ & $20.00^{f}$ & $20.00^{\mathrm{g}}$ & $\mathrm{F}$ & $\mathrm{G}$ & ++ & $20.00^{\mathrm{g}}$ & $30.00^{\mathrm{h}}$ & $\mathrm{F}$ & $\mathrm{G}$ & ++ \\
\hline $\mathrm{SI}_{23}$ & - & 1.5 & - & - & - & - & $0.00^{\mathrm{h}}$ & $0.00^{\mathrm{g}}$ & $0.00^{\mathrm{g}}$ & NR & ND & ++ & $0.00^{\mathrm{h}}$ & $0.00^{\mathrm{h}}$ & NR & ND & ++ & $0.00^{\mathrm{h}}$ & $0.00^{t}$ & NR & ND & ++ \\
\hline $\mathrm{SI}_{24}$ & - & 2.5 & - & - & - & - & $36.50^{\mathrm{df}}$ & $50.00^{\mathrm{a}}$ & $50.00^{\mathrm{a}}$ & $\mathrm{F}$ & $\mathrm{G}$ & ++++ & $70.00^{\mathrm{a}}$ & $50.00^{c}$ & $\mathrm{~F}$ & G & ++++ & $80.00^{\mathrm{b}}$ & $70.00^{\mathrm{b}}$ & $\mathrm{F}$ & $\begin{array}{c}\mathrm{G}+ \\
\mathrm{Y}\end{array}$ & ++++ \\
\hline $\mathrm{SI}_{25}$ & - & 2.0 & - & - & - & - & $35.75^{\mathrm{a}}$ & $30.00^{c}$ & $20.00^{\mathrm{d}}$ & $\mathrm{F}$ & $\mathrm{G}$ & +++ & $20.00^{f}$ & $40.00^{\mathrm{d}}$ & $\mathrm{F}$ & G & +++ & $40.00^{\mathrm{d}}$ & $60.00^{\mathrm{d}}$ & $\mathrm{F}$ & $\mathrm{G}$ & +++ \\
\hline $\mathrm{SI}_{26}$ & - & 3.5 & - & - & - & - & $0.00^{h}$ & $0.00^{\mathrm{g}}$ & $0.00^{\mathrm{g}}$ & NR & ND & + & $0.00^{\mathrm{h}}$ & $0.00^{\mathrm{h}}$ & NR & ND & + & $0.00^{\mathrm{h}}$ & $0.00^{\mathrm{t}}$ & NR & ND & + \\
\hline $\mathrm{SI}_{27}$ & - & 4.0 & - & - & - & - & $0.00^{h}$ & $0.00^{\mathrm{g}}$ & $0.00^{\mathrm{g}}$ & NR & ND & + & $0.00^{\mathrm{h}}$ & $0.00^{h}$ & NR & ND & + & $0.00^{h}$ & $0.00^{t}$ & NR & ND & + \\
\hline $\mathrm{SI}_{28}$ & - & 4.5 & - & - & - & - & $0.00^{h}$ & $0.00^{\mathrm{g}}$ & $0.00^{\mathrm{g}}$ & NR & ND & + & $0.00^{\mathrm{h}}$ & $0.00^{h}$ & NR & ND & + & $0.00^{h}$ & $0.00^{t}$ & NR & ND & + \\
\hline $\mathrm{SI}_{29}$ & - & 5.0 & - & - & - & - & $0.00^{h}$ & $0.00^{\mathrm{g}}$ & $0.00^{\mathrm{g}}$ & NR & ND & + & $0.00^{\mathrm{h}}$ & $0.00^{h}$ & NR & ND & + & $0.00^{h}$ & $0.00^{t}$ & NR & ND & + \\
\hline $\mathrm{SI}_{30}$ & - & 3.0 & - & - & - & - & $0.00^{\mathrm{h}}$ & $0.00^{\mathrm{g}}$ & $0.00^{\mathrm{g}}$ & NR & ND & + & $0.00^{\mathrm{h}}$ & $0.00^{\mathrm{h}}$ & NR & ND & + & $0.00^{\mathrm{h}}$ & $0.00^{t}$ & NR & ND & + \\
\hline $\mathrm{SI}_{31}$ & 0.0 & 0.5 & - & - & - & - & $0.00^{h}$ & $0.00^{\mathrm{g}}$ & $0.00^{\mathrm{g}}$ & NR & ND & + & $0.00^{\mathrm{h}}$ & $0.00^{h}$ & NR & ND & + & $0.00^{h}$ & $0.00^{t}$ & NR & ND & + \\
\hline $\mathrm{SI}_{32}$ & 1.0 & 0.0 & - & - & - & - & $0.00^{h}$ & $0.00^{\mathrm{g}}$ & $0.00^{\mathrm{g}}$ & NR & ND & + & $0.00^{\mathrm{h}}$ & $0.00^{\mathrm{h}}$ & NR & ND & + & $0.00^{h}$ & $0.00^{\mathrm{t}}$ & NR & ND & + \\
\hline $\mathrm{SI}_{33}$ & 1.0 & 0.5 & - & - & - & - & $37.00^{\mathrm{a}}$ & $40.00^{\mathrm{b}}$ & $37.50^{\mathrm{b}}$ & $\mathrm{F}$ & $\mathrm{G}$ & ++++ & $60.00^{\mathrm{b}}$ & $62.50^{\mathrm{b}}$ & $\mathrm{F}$ & $\mathrm{G}$ & ++++ & $87.50^{\mathrm{a}}$ & $75.00^{\mathrm{a}}$ & $\mathrm{F}$ & $\mathrm{G}$ & ++++ \\
\hline
\end{tabular}




\begin{tabular}{|c|c|c|c|c|c|c|c|c|c|c|c|c|c|c|c|c|c|c|c|c|c|c|}
\hline \multirow[b]{2}{*}{$\begin{array}{c}\text { Media } \\
\text { Code }\end{array}$} & \multicolumn{6}{|c|}{ PGRs } & \multicolumn{6}{|c|}{ After 40 days } & \multicolumn{5}{|c|}{ After 80 days } & \multicolumn{5}{|c|}{ After 120 days } \\
\hline & $\begin{array}{c}\text { BAP } \\
(\mathbf{m g l} \\
1 \text { ) }\end{array}$ & $\begin{array}{c}2,4- \\
\text { D } \\
(\mathbf{m g l} \\
1)\end{array}$ & $\begin{array}{c}\text { Glycine } \\
\left(\mathbf{m g l}^{-1}\right)\end{array}$ & $\begin{array}{c}\text { ADS } \\
(\mathbf{m g l} \\
1 \text { ) }\end{array}$ & $\begin{array}{l}\mathrm{KNO}_{3} \\
\left(\mathrm{mgl}^{-1}\right)\end{array}$ & $\begin{array}{c}\text { NAA } \\
\left(\begin{array}{c}\text { mgl- } \\
\text { 1) }\end{array}\right.\end{array}$ & $\begin{array}{c}\text { Days to } \\
\text { callus } \\
\text { induction }\end{array}$ & $\begin{array}{c}\begin{array}{c}\text { Callus } \\
\text { induction } \\
(\%)\end{array} \\
\text { ( })\end{array}$ & $\begin{array}{c}\text { Callus } \\
\text { frequency } \\
(\%)\end{array}$ & $\begin{array}{c}\text { Callus } \\
\text { type }\end{array}$ & $\begin{array}{l}\text { Callus } \\
\text { colour }\end{array}$ & $\begin{array}{l}\text { Health } \\
\text { range }\end{array}$ & $\begin{array}{c}\text { Callus } \\
\text { induction } \\
(\%)\end{array}$ & $\begin{array}{c}\text { Callus } \\
\text { frequency } \\
(\%)\end{array}$ & $\begin{array}{c}\text { Callus } \\
\text { type }\end{array}$ & $\begin{array}{l}\text { Callus } \\
\text { colour }\end{array}$ & $\begin{array}{l}\text { Health } \\
\text { range }\end{array}$ & $\begin{array}{c}\text { Callus } \\
\text { Induction } \\
(\%)\end{array}$ & $\begin{array}{c}\text { Callus } \\
\text { regeneration } \\
\text { frequency } \\
(\%)\end{array}$ & $\begin{array}{c}\text { Callus } \\
\text { type }\end{array}$ & $\begin{array}{l}\text { Callus } \\
\text { colour }\end{array}$ & $\begin{array}{c}\text { Health } \\
\text { range }\end{array}$ \\
\hline $\mathrm{SI}_{34}$ & 2.0 & 0.0 & - & - & - & - & $0.00^{h}$ & $0.00^{\mathrm{g}}$ & $0.00^{\mathrm{g}}$ & NR & ND & + & $0.00^{h}$ & $0.00^{h}$ & NR & ND & + & $0.00^{h}$ & $0.00^{t}$ & NR & ND & + \\
\hline $\mathrm{SI}_{35}$ & 2.0 & 0.5 & - & - & - & - & $36.75^{\mathrm{ab}}$ & $10.00^{\mathrm{f}}$ & $20.00^{\mathrm{d}}$ & $\mathrm{F}$ & $\mathrm{G}$ & ++++ & $30.00^{\mathrm{d}}$ & $40.00^{\mathrm{d}}$ & $\mathrm{F}$ & $\mathrm{G}$ & ++++ & $80.00^{\mathrm{b}}$ & $72.50^{\mathrm{ab}}$ & $\mathrm{F}$ & $\mathrm{G}$ & ++++ \\
\hline $\mathrm{SI}_{36}$ & 4.0 & 0.0 & - & - & - & 0.4 & $0.00^{\mathrm{h}}$ & $0.00^{\mathrm{g}}$ & $0.00^{\mathrm{g}}$ & NR & ND & + & $0.00^{\mathrm{h}}$ & $0.00^{\mathrm{h}}$ & NR & ND & + & $0.00^{\mathrm{h}}$ & $0.00^{\mathrm{t}}$ & NR & ND & + \\
\hline \multirow{3}{*}{\multicolumn{2}{|c|}{$\begin{array}{l}\text { S.Em. } \\
\text { C.D. at } 5 \% \\
\text { C. V. } \%\end{array}$}} & & & & & & 0.134 & 0.417 & 0.417 & & & & 0.417 & 1.049 & & & & 1.179 & 1.318 & & & \\
\hline & & & & & & & 0.375 & 1.167 & 1.167 & & & & 1.167 & 2.936 & & & & 3.300 & 3.689 & & & \\
\hline & & & & & & & 6.21 & 6.15 & 8.39 & & & & 5.38 & 9.77 & & & & 9.48 & 9.30 & & & \\
\hline
\end{tabular}

reatment means with same letters were at par at $5 \%$ levero

PGRs - Plant Growth Regulators. G - Green. Y - Yellow. G + Y - Greenish yellow. C - Compact callus texture, F - Friable callus texture. ND- Not detected. NR - No response. + Poor, ++ Moderate, +++ Healthy, ++++ Very healthy 